\title{
An institutional approach and input- output analysis for explaining the transformation of the Turkish economy
}

\author{
Emre Ünal ${ }^{*}$ (D)
}

\section{*Correspondence:}

emunal@gelisim.edu.tr Department of International Trade, Faculty of Economics, Administrative and Social Sciences, Istanbul Gelisim University, Cihangir Mahallesi Şehit Piyade Onbaşı Murat Şengöz Sokak No:8, 34310 Avcllar/Istanbul, Turkey

\begin{abstract}
The increasing inconsistency in the Turkish economy gave rise to transformations necessitated by the manner of its growth and technological changes. Between 1923 and 1962, the Turkish economy was based on agricultural growth strategies, which spurred development in the manufacturing sector and caused technological change. Between 1962 and 1985, the Turkish economy developed under import substitution industrialization, with regulations based on domestic consumption growth strategies. In the early 1980s, most of the developed countries, in parallel with which Turkey had development policies, implemented strong institutional changes via deregulation policies, but Turkey could not produce the necessary configurations in accord with open and export growth economies. The period between 1985 and 2003 was a long transformational period for Turkey vying to be a stable export growth country. This slow transformation was caused by path dependency and had been based on regulations that destabilized Turkey and deepened problems remaining from previous periods. Post-2003, the Turkish economy was able to develop more consistent export growth by forced institutional changes, but its macroeconomic factors still do not show institutional complementarity.
\end{abstract}

Keywords: Agricultural growth, Domestic consumption growth, Export growth, Institutional factors, Stylized facts of structural transformation, Input-output analysis

JEL Classification: C6, E6, F4, O4

\section{Introduction}

In this paper, the main questions are: First, what were Turkey's transformation periods, and what conditions furnished basis of technological changes? Second, what is Turkey's growth model, and why it is still far from institutional complementarity? Two main concepts, growth models and institutional factors, can be used to define the economic and social changes in an economy. These concepts not only point out economic and political problems, but also effect a compromise between institutional changes and growth models, which serve to describe necessary arrangements inside an economy and help realize institutional complementarity between macroeconomic and institutional factors. Hence, using an institutional approach will enable exploration of the connection between regulation in a capitalist economy and its historical evolution

(c) The Author(s) 2018. This article is distributed under the terms of the Creative Commons Attribution 4.0 International License (http://creativecommons.org/licenses/by/4.0/), which permits unrestricted use, distribution, and reproduction in any medium, provided you give appropriate credit to the original author(s) and the source, provide a link to the Creative Commons license, and indicate if changes were made. 
(Jessop and Sum 2006a, b: 1-3). Regulations emerge as a result of a change in a production system based on macroeconomic factors, which can be defined by growth models. As the production system changes in an economy, regulations usually remain slow, which causes an economy to follow radical institutional changes to create a compromise between the growth model and institutional factors. However, that does not mean each institutional change can create institutional complementarity based on macroeconomic factors. One of the reasons for the slowing of growth in the Turkish economy pre-2003 was its slow regulations under the dysfunctional governments. Radical regulations were practically established or supported after low economic performance in Turkey in the 1960s, which transformed the economy into one which was closed and protected, with import substitution industrialization based on domestic consumption growth after technological change from agricultural growth. In the early 1980s, increasing economic and political problems weakened government and gave way to new institutional changes and supported regulations for export growth. Nevertheless, the period of 1985-2003 remained a long transformation process for the Turkish economy. Finally, in the 2000s, regulations which made the Turkish economy stronger compared to that of the pre-2003 period were created by the government and supported by international organizations such as the IMF, the World Bank and the EU. ${ }^{1}$

The main reasons for economic crises in Turkey are flaws in its institutional factors, which conflicted with its macroeconomic factors. To avoid similar crises in future, institutional factors should be evaluated and reformed. Possible reforms that may occur in institutional factors could eliminate the influence of a crisis and stabilize the economy. Therefore, to create new institutional changes, the current growth model in an economy must be properly known and understood. In this work, Turkey and its growth strategies particularly from 1950 are considered. The Turkish economy went through several important periods. These periods were 1923-1962, 1962-1985, 1985-2003 and post2003. The main institutional changes that influenced and contributed to the future of the Turkish economy emerged in the periods after economic crises.

The institutional changes used in this paper are inspired by the régulation theory. According to the régulation theory, there are five institutional factors: bank and credit relations, wage and labor relations, mode of competition, mode of international insertion and the role of government (Boyer 1990: 38-39; Boyer and Hollingsworth 1997: 49-54; Boyer and Saillard 2002: 44). However, these concepts encapsulate many factors. To make it more descriptive, the important concepts that influenced the Turkish economy over time are used, and summarized in Table 8. The wage-labor relation is one of the important concepts of the régulation theory (Boyer and Yamada 2000: 10). The wage-labor relation can be influenced by income policies related to trade unions and modes of employment. Therefore, wage-labor relations consist of productivity growth, wage growth, and their interaction with inflation in the economy. The position of labor in sectors will be taken into account. Another important concept for the Turkish economy is related to exchange rate systems. The position of a country in international insertion can consist of exchange rate and competitiveness, which affect the trade balance,

${ }^{1}$ The Justice and Development Party, Erdoğan's government began implementing regulations as only governing party in the parliment. 
and is influenced by productivity growth and wage rate growth inside the economy. The production base of the important industries will be considered, and the role of privatizations in the economy will be highlighted. The mode of economy is depended on the macroeconomic perspectives of an open or closed economy. The government, with its regulatory intervention and role in the economy, will be considered.

There are plenty of works in which to find institutional changes in the developed countries, and some works about the Latin American countries, which define their growth regimes and institutional factors (Aboites et al. 2002: 280-287). There have been some works which have analyzed the Turkish economy from an institutional perspective in order to explain its transformation in terms of macroeconomic and institutional factors, including wage-labor relations and exchange rate systems (Ünal 2016a, b, 2017). In that work, which differs from previous research, the Turkish economy is analyzed using broad concepts of institutional factors, and with a deeper theoretical and historical perspective, covering important periods of the economy when chronic problems emerged. In Sect. 2, stylized facts of structural transformation are discussed. The macroeconomic growth models designed by input-output analysis and assumptions are explained. In Sect. 3, major developed countries (Canada, France, Japan, the Netherlands, the United Kingdom and the United States) were briefly examined in terms of stylized facts of structural transformation, macroeconomic and institutional factors. In Sect. 4, Turkey's transformation from agricultural growth to domestic consumption growth is identified. Institutional factors in the period of agricultural growth are examined, and the reasons for the economic crisis in that period are discussed. Because of its parallel institutional factors, Turkey is compared with the developed countries by deriving input-output tables. Moreover, institutional changes that shaped domestic consumption growth in the period of 1962-1985 are explained, and the reasons for economic crisis under the domestic growth policies are clarified. In addition, the transformation into export growth is depicted in terms of institutional factors, and the importance of the 20002001 economic crisis is extensively discussed. Finally, in Table 8, macroeconomic and institutional factors, in the context of their periods, are clearly laid out.

\section{Stylized facts of structural transformation and macroeconomic growth models}

Kuznets (1973) asserted that there are fundamental factors of economic growth that distribute economic goods to its population. These are advancing technology, and institutional and ideological adjustments. These factors change over time and regions. $\mathrm{He}$ highlighted facts about modern economic growth that cover rapid growth of population and per capita product, productivity growth, consumption and distribution of workers in sectors for structural transformation that is defined by a shift from the agricultural to the non-agricultural sector, and from the manufacturing to the service sector, and he considered the manufacturing sector a driving force for economic development. ${ }^{2}$ Kaldor (1961) highlighted stylized facts as regards the process of economic change and

\footnotetext{
${ }^{2}$ Labor shift between sectors are important components of economic development. The countries which do not experience structural transformation between sectors generally remain poor and less developed. For sectoral classification, see Kuznets (1957).
} 
development in advanced capitalist countries. Some of these facts are about the distinction features of labor productivity, capital and output in economy. He considered exportled growth as a key factor for economic growth and pointed that the British economy lagged behind because of its consumption-led growth. ${ }^{3}$ For Solow (1970), technological upgrading is the source of increased productivity. In other words, productivity growth is an important measurement for describing structural transformation by defining the relation between output and input variables such as labor and capital. Verdoorn (2003) pointed out that productivity growth is connected with output and employment, and considered the productivity growth of the manufacturing sector as a significant factor for economic growth, and its elasticity with production in various countries. ${ }^{4}$

These works give clues to help us define structural transformation in economies. The standard transformation for an economy is from the agriculture to the manufacturing and service sectors, which result in increasing GDP, GDP per capita, productivity and a shift from low- and medium-tech industries to medium- and high-tech industries. In such a transformation, a developed industry leads labor to move to other developing industries. For instance, experiencing high productivity growth through low-cost production and mechanization in the agricultural sector enhances the manufacturing sector where labor desires to move and reproduce itself. This transformation creates a new dominant sector and contributes to economic development. In other words, structural transformation from the agricultural sector to the manufacturing sector gives rise to industrialization and develops a path toward a technological frontier.

Economic development creates two economic conditions: "standard" and "revolutionary." A standard economic condition indicates a transformation as workers move from agriculture to a developing manufacturing sector. ${ }^{5}$ Revolutionary economic conditions emphasize technological change and increasing productivity when workers become more sophisticated in the use of technologies and gain the organizational skills to engage in the domestic and export goods sectors, which contribute to economic development. In this respect, structural transformation also means more complicated production processes and higher productivity growth. Structural transformation creates new leading sectors, leads to new organization of workers and facilitates technological upgrading. What define a standard structural transformation are the stylized facts: Sectoral shares of workers, value-added, production, and export.

\subsection{Describing structural transformation with macroeconomic and institutional factors}

From the 1950s to the early 1970s, national data, which gave detailed information about production in the agricultural, manufacturing and service sectors, and employment

\footnotetext{
${ }^{3}$ For additional information see King (2009: 77) and Uni (2007).

4 There are also some other works considered modern economic theories to explain structural transformation by using stylized facts. Herrendorf et al. (2013) used employment and value-added shares in sectors and pointed the developed countries usually experiences downward process in the value-added share of manufacturing after it reaches a certain extent, whereas agriculture generally decreases. Thus, the service sector gains importance. Michaels et al. (2012) examined structural transformation by six stylized facts to describe population shift across rural and urban areas. Briones and Felipe (2013) briefly mentioned that although developing Asian countries experienced structural transformation, agriculture has kept its important position. The sector's employment share and output were still at significant level.

5 This technological transformation can also be explained by flying geese theory. Turkey experienced large amount of foreign direct investment inflows from developed EU countries such as Germany and Netherlands in the 2000s. For additional information, see Ünal (2017).
} 
statistics, was used to define technological change and structural transformation in Turkey. The input-output tables of Turkey were derived from TurkStat and WIOD. The input-output tables used from TurkStat cover the years 1973 and 1985. Whereas the 1973 table is a descriptive source for indicating domestic consumption growth, the 1985 table is a source of describing technological change in comparison with the previous and subsequent period. TurkStat released detailed $(64 \times 64)$ tables but did not provide employment information. Hence, the tables were aggregated to nine main industries, and TurkStat employment data was used to calculate the productivity growth of nontradable and export goods sectors. ${ }^{6}$ Although WIOD 2003 and $2011(35 \times 35)$ tables provide employment data, the sectoral price deflators were not provided for non-tradable and export goods; thus, the deflators were collected from UN data. For this kind of study, although there was some lack of data, additional sources helped the study became more substantial. Had TurkStat included detailed employment information, it could have helped calculate productivity growth; and had WIOD released sectoral price deflators for export industries it would even have been possible to analyze the role of industries in the export goods sector. Nevertheless, the tables are sufficient to show technological change and the shift in dominance between the non-tradable goods and export goods sectors.

Although it is controversial to compare a developing country such as Turkey with developed countries, it is a fact that Turkey experienced macroeconomic factors and followed institutional changes in parallel with developed countries, whether successfully or not. Moreover, OECD input-output tables for developed countries provide an opportunity to compare Turkey with these countries. ${ }^{7}$

The Turkish economic transformation can be analyzed by commodity base productivity growth calculation via input-output tables. This method of calculation gives information about dynamic developments in the economy and helps understand the role of the productivity growth of export goods, which is the driving force of economic growth in export growth countries. Furthermore, increasing productivity in the export goods sector means that much more complicated products begin to be transacted, namely, technological change emerges related to a revolutionary economic condition. To find the productivity growth rates, labor input is used to divide sectors into non-tradable goods and export goods, which are specific conceptions intended to create macroeconomic factors to explain structural transformation from the 1970s onward. Although technological transformation plays a crucial role in enabling developing economies to catch up, lack of proper institutional changes can be a barrier. In addition, different development paths require different institutional forms. Therefore, unfavorable institutional changes can cause slow economic development and slow structural transformation.

Conclusively, there is a standard development path for developing countries, but if institutional factors are not defined properly, this causes slow transformation and the country lags behind. In other words, the development potential of countries might be limited. To understand the Turkish economic transformation better, macroeconomic

\footnotetext{
${ }^{6}$ For employment data see TurkStat, statistics of employed persons by type of economic activity, report "Statistical Indicators 1923-2011."

7 It is difficult to find 1970s' input-output tables for developing countries because most of them were the part of communist economy.
} 
growth models are considered in order to identify institutional problems. However, eliminating potential problems requires a macroeconomic growth model to define economic conditions. These models are mostly categorized by macroeconomic factors to provide a favorable analysis, so the institutional factors suitable for a structural transformation must be well-understood. So the fundamental structural transformation paths categorized in this paper are agricultural growth, domestic consumption growth and export growth.

\subsection{Macroeconomic growth models}

Agricultural growth emerges at the first stage of industrialization, usually spurring the manufacturing sector to grow and become the leading sector in an economy in subsequent years. One of the defining features of an agricultural growth country is that its productivity growth is greater than that of manufacturing. After experiencing a technological change to the manufacturing sector, complicated commodities are used in the production process; thus, labor cost, import material costs and mark-up rates gain prominence.

The growth models assume that there is proportional wage growth between the nontradable and export goods sectors. According to Table 9, all seven countries had proportional wage growth between the two sectors. Moreover, the assumptions of a constant mark-up rate and negligible import costs are important variables in the models. However, differences between the price levels emerge due to proportional wage growth, ${ }^{8}$ but disproportional productivity growth of non-tradable goods and export goods. ${ }^{9}$ To explain more clearly, two countries are used in the models. Country A is shown with superscript $A$ and country B with $B$.

The one of the reasons that Turkey had a closed economy in the 1970s was because of a global trend in economic policies. Developed countries mostly had high proportional wage rate growth that surpassed their productivity growth rates, and experienced high inflation. In other words, they had a "domestic consumption growth model" which means the productivity growth of non-tradable goods $\left(\hat{q}_{\mathrm{n}}^{A}\right)$ was higher than that of exports goods $\left(\hat{q}_{\mathrm{e}}^{A}\right)$. Subscript $\mathrm{n}$ and $\mathrm{e}$ indicates non-tradable goods and export goods, respectively. $(\wedge)$ indicates growth rate (see appendix in detail). The economic model of the 1970s can be described as follows:

$$
\hat{w}^{A}>\hat{q}_{\mathrm{n}}^{A}>\hat{q}_{\mathrm{e}}^{A} \quad \text { and } \quad \hat{q}_{\mathrm{e}}^{B}=\hat{q}_{\mathrm{n}}^{B}=\hat{w}^{B}
$$

\footnotetext{
${ }^{8}$ The price level $(p)$ is based on vertically integrated labor input coefficients $(v)$ (see Appendix for the calculation method), nominal wage rate $(w)$, mark-up rate $(m)$, and imported material cost $\left(c_{\text {im }}\right)$ as follows: $p=(1+m)$ $\left(w v+c_{\mathrm{im}}\right)$. Here, price is divided into the price of non-tradable goods and export goods. Subscript $\mathrm{n}$ and e represents non-tradable and export goods respectively as follows: $p_{\mathrm{n}}=\left(1+m_{\mathrm{n}}\right)\left(w v_{\mathrm{n}}+c_{\mathrm{im}}\right)$ and $p_{\mathrm{e}}=\left(1+m_{\mathrm{e}}\right)\left(w v_{\mathrm{e}}+c_{\mathrm{im}}\right)$. To get the purchasing power parity (PPP), the export price is considered between two countries (A and B) as follows: $P P P \times$ export price of country $A=$ export price of country $B, q$ indicates productivity and $\left(^{\wedge}\right)$ indicates growth. As the part of assumptions, in conditions of negligible import cost, PPP was calculated between the two countries as follows: $\hat{P P} P^{A}=\left[\left({\widehat{1+m_{\mathrm{e}}}}^{B}\right)+\hat{w}^{B}-\hat{q}_{\mathrm{e}}^{B}\right]-\left[\left({\widehat{1+m_{\mathrm{e}}}}^{A}\right)+\hat{w}^{A}-\hat{q}_{\mathrm{e}}^{A}\right]$. PPP is the hypothetical exchange rate. Price levels can be calculated from the United Nations data "National Accounts Estimates of Main Aggregates" (http://data.un.org/ Explorer.aspx?d=SNA). For export price level, export at current prices (national currency) and export at constant prices (national currency) are considered. The price level of non-tradable goods was calculated by considering respectively both current and constant prices; domestic demand $=G D P-$ export + import.

${ }^{9}$ Proportional wage rate growth can be approximately calculated by considering change rates in price levels and productivity growth, calculated via input-output analysis as follows: $\hat{w}_{e}=\hat{p}_{e}+\hat{q}_{e}-\left(\widehat{1+m}_{e}\right)$ and $\hat{w}_{n}=\hat{p}_{n}+\hat{q}_{n}-\left(\widehat{1+m_{n}}\right)$.
} 
In model (1), in country A, because high social welfare systems served to protect trade unions and support domestic consumption, the proportional wage rate growth $\left(\hat{w}^{A}\right)$ is larger than the productivity growth of non-tradable goods. Also, the productivity growth of non-tradable goods is greater than the productivity growth of export goods because international trade is secondary, and not promoted, which decreases the efficiency of export goods sector, causing slow productivity growth. In the country A, inflation is high, and it is less competitive under the fixed exchange rate system compared with that of country B. Country B shows a perfect economy under equal macroeconomic factors.

Export growth became dominant in the 1980s, when many countries abandoned closed economic policies and focused on export growth to increase their competitiveness in international trade. To do that, countries scrapped welfare programs and reduced the power of trade unions to eliminate inflation and decrease unit labor cost (ULC). ${ }^{10}$ Therefore, in the 1980s, wage rate growth showed a declining trend compared with the 1960s and 1970s. Export growth models can be explained by a low-cost production model and the Balassa-Samuelson model.

$$
\hat{q}_{\mathrm{e}}^{A}>\hat{q}_{\mathrm{n}}^{A}=\hat{w}^{A} \quad \text { and } \quad \hat{q}_{\mathrm{e}}^{B}=\hat{q}_{\mathrm{n}}^{B}=\hat{w}^{B}
$$

The Eq. (2) shows a "low-cost production model." In that model, wage rate growth is fixed to the productivity growth of non-tradable goods, which creates low ULC growth in the export goods sector and hence increases competitiveness in the international context. Under a floating exchange rate, country A has increasing PPP, which means the country will experience appreciations in its national currency because the change in the exchange rate moves in parallel with that of PPP.

$$
\hat{w}^{A}=\hat{q}_{\mathrm{e}}^{A}>\hat{q}_{\mathrm{n}}^{A} \quad \text { and } \quad \hat{q}_{\mathrm{e}}^{B}=\hat{q}_{\mathrm{n}}^{B}=\hat{w}^{B}
$$

The Eq. (3) reflects the "Balassa-Samuelson model."11 The assumption of this model is based on proportional wage growth, but disproportional productivity growth. In that model, wage rate growth is fixed to the productivity growth of export goods and the productivity growth of export goods is larger than the productivity growth of non-tradable goods under the fixed exchange rate system. In that model, because of disproportional productivity growth (export-biased productivity growth) between two sectors, high inflation emerges. ${ }^{12}$

\subsubsection{The over-valued currency model and institutional complementarity}

When the other countries in international trade shifted to the low-cost production model and the Balassa-Samuelson model in the 1980s, Turkey, which could not implement necessary institutional changes, fell into the "over-valued currency model," with high productivity growth of export goods compared with that of non-tradable goods. If the country cannot implement necessary institutional changes, because of highcost production and an over-valued currency, it will produce high inflation, lose its

\footnotetext{
10 The method of ULC growth rates of export goods and non-tradable goods: $U \hat{L} C_{e}=\hat{w}_{e}-\hat{q}_{e}$ and $U \hat{L} C_{n}=\hat{w}_{n}-\hat{q}_{n}$.

11 For additional information see Balassa (1964), Samuelson (1964), Uni (2012) and Ünal (2016b).

12 For additional information about EMU and export-led growth models based on analysis in the 2000s, see Ünal (2016a, b).
} 
competitiveness, have a high trade deficit and create an economy, which is exposed to economic turmoil and large devaluations in its exchange rate. The over-valued currency model is defined as follows:

$$
\hat{w}^{A}>\hat{q}_{\mathrm{e}}^{A}>\hat{q}_{\mathrm{n}}^{A} \quad \text { and } \quad \hat{q}_{\mathrm{e}}^{B}=\hat{q}_{\mathrm{n}}^{B}=\hat{w}^{B}
$$

In that model, the exchange rate system can be fixed or floating, but is repressed by central banks to remain over-valued. That model basically reflects the Turkish economy in the post-1980s. An economy which has that growth model suffers because of high inflation, dramatic depreciations in the exchange rate, low competitiveness and a high trade deficit relative to country B. In that model, a national currency is over-valued, which means its appreciation rate is higher than that of PPP. To generate institutional complementarity between macroeconomic and institutional factors for export growth, wage rate growth must fall to at least that of productivity growth of export goods.

\section{Structural transformation in major developed countries}

Figure 1 shows the relationship between the distribution of workers among the three main sectors and their movements with GDP in the major developed countries. The countries were chosen for the analysis because of their available input-output tables in the same periods to discuss development process in the 1970s and 1980s (see Table 1). What is generally seen on Fig. 1 is consistent decline in the sectoral share of workers in the agricultural sector, whereas steady increase in that of workers in service sector. Furthermore, the sectoral share of workers in the manufacturing sector in the developed countries except in Japan indicates more visible downward inclination toward the 1970s. The sectoral share of value-added in the three sectors in all countries moved differently (see Fig. 6 in Appendix). Whereas the sectoral share of manufacturing sector indicated downward process in the 1970s that of service sector was seen as attracting more workers and contributing more for value-added. In addition, the sectoral share of production in the manufacturing sector decreased and that in service sector became dominant toward the 1990s in the developed countries (see Table 10 in Appendix). As these countries had already developed manufacturing sector, the sectoral share of export in the manufacturing sector compared with others were more significant. ${ }^{13}$

The curves of the countries discussed in Fig. 1 showed similar patterns in the selected years. Furthermore, the macroeconomic factors of the developed countries moved almost in parallel with each other in the 1970s and 1980s. In these countries, wage growth, which had been supported by welfare state policy, was high. In this kind of policy, the main aim was to give workers purchasing power to provide effective demand for domestic production, and this influenced the productivity growth of non-tradable goods. Thus, inflation and labor cost growth were high. Productivity growth was based on the non-tradable goods sector because domestic consumption was the main policy

\footnotetext{
13 The contribution of the service sector to export was very low in Turkey compared with those of developed countries. For instance, the sectoral share of exports in the service sector was 17.0 in Canada, 23.3 in France, 17.3 in the United Kingdom, 15.8 in Japan, 26.4 in the United States in 1990, and 19.9 in Netherlands in 1986, but in Turkey it was just 0.7 in 2014. As the major countries had developed industrialization long before these periods, there was no clear indication that could help define structural transformation by the ratio of export to import, but sectoral wage growth was usually higher in the service sector than in the manufacturing sector, and that of the manufacturing sector was higher than that of the agricultural sector. Source: OECD input-output tables.
} 


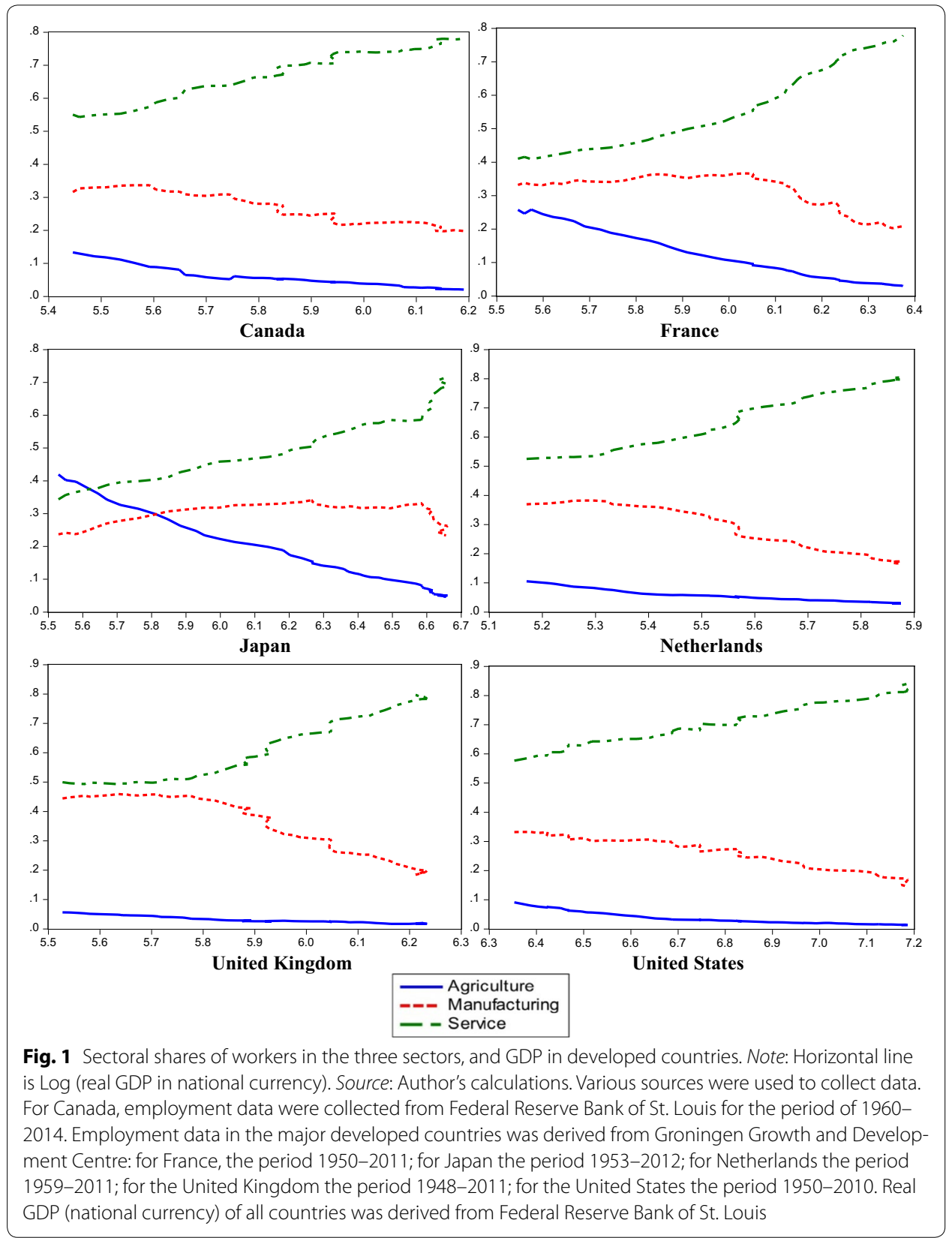

all of these countries before the 1980s, and international trade was a secondary consideration. In other words, protected and regulated economies were dominant. When the sectoral shares of workers in the manufacturing sector started to decline toward or in the 1970s, domestic consumption growth was clearly visible (see Table 1). The same situation emerged in the sectoral share of value-added in the three sectors of the countries (see Fig. 6). Hence, it can be said that the development path of the developed countries changed in the 1970s and that drove workers into the service sector. In the 1980s, the sectoral share of workers in the manufacturing sector continued to decrease steadily, whereas in the service sector it increased. The gap between the sectoral shares of workers in the manufacturing and service sectors widened. The sectoral share of value-added 
Table 1 Domestic consumption growth and export growth by country (annual rate, unit: \%). Source: Author's calculations. The OECD tables aggregated to nine main industries were used to calculate productivity growth. Inflation rates for the Netherlands and the United Kingdom were derived from OECD (consumer price), and those of other countries were derived from the World Bank (inflation, consumer price). Wage growth was derived from the OECD tables, and employment was derived from the ILO (Wage rate growth was proportional in both non-tradable goods and export goods, and imported material costs were negligible. However, countries did not have constant mark-up rate growth. For additional information, see Ünal (2016a). For Turkey, 1973 and 1985 were derived from TurkStat and WIOD tables were used to calculate productivity growth between 2003 and 2011

\begin{tabular}{|c|c|c|c|c|c|c|}
\hline Country & Period & $\begin{array}{l}\text { Growth } \\
\text { of mark-up } \\
\text { rate }\left(1+m_{n}\right)^{\text {a }}\end{array}$ & $\begin{array}{l}\text { Productivity } \\
\text { growth of non- } \\
\text { tradable goods }\end{array}$ & $\begin{array}{l}\text { Productivity } \\
\text { growth of } \\
\text { export goods }\end{array}$ & $\begin{array}{l}\text { Wage } \\
\text { rate } \\
\text { growth }\end{array}$ & Inflation \\
\hline \multirow[t]{4}{*}{ Canada } & 1971-1976 & -0.6 & 1.2 & -0.4 & 11.0 & 7.4 \\
\hline & 1976-1981 & 0.8 & 0.8 & -0.9 & 8.6 & 9.4 \\
\hline & 1981-1986 & 0.4 & 0.9 & 5.4 & 5.3 & 6.9 \\
\hline & 1986-1990 & -0.7 & 0.8 & 3.5 & 5.5 & 4.5 \\
\hline \multirow[t]{4}{*}{ France } & 1972-1977 & 2.8 & 6.0 & 4.5 & 13.5 & 9.5 \\
\hline & 1977-1980 & 0.0 & 2.6 & 3.0 & 12.8 & 10.7 \\
\hline & 1980-1985 & 0.7 & 1.7 & 2.1 & 9.8 & 10.3 \\
\hline & 1985-1990 & 1.0 & 2.2 & 5.6 & 4.2 & 3.5 \\
\hline \multirow[t]{2}{*}{ Japan } & 1970-1980 & -1.6 & 3.8 & 6.6 & 13.3 & 8.9 \\
\hline & 1980-1990 & 3.0 & 6.2 & 9.2 & 4.5 & 2.5 \\
\hline \multirow[t]{3}{*}{ Netherlands } & 1972-1977 & 1.5 & 3.5 & 3.4 & 10.7 & 8.4 \\
\hline & 1977-1981 & 2.5 & 2.1 & 1.4 & 4.4 & 5.5 \\
\hline & 1981-1986 & 4.2 & 4.5 & 7.0 & 2.3 & 3.5 \\
\hline \multirow[t]{3}{*}{ Turkey } & 1973-1985 & 3.8 & 3.8 & 2.0 & 34.2 & 38.5 \\
\hline & 1985-2003 & 0.4 & 3.0 & 5.3 & 66.2 & 63.5 \\
\hline & 2003-2011 & 0.7 & 2.7 & 3.7 & 11.2 & 10.6 \\
\hline \multirow{3}{*}{$\begin{array}{l}\text { United King- } \\
\text { dom }\end{array}$} & 1968-1979 & -2.6 & 2.9 & 2.1 & 13.4 & 11.4 \\
\hline & 1979-1984 & 0.5 & 1.0 & 4.8 & 9.8 & 10.2 \\
\hline & 1984-1990 & 0.3 & 1.8 & 2.3 & 7.2 & 4.9 \\
\hline \multirow[t]{4}{*}{ United States } & 1972-1977 & 0.9 & 1.1 & -1.5 & 7.3 & 7.0 \\
\hline & 1977-1982 & 0.1 & 0.4 & 0.7 & 8.1 & 9.2 \\
\hline & 1982-1985 & -0.1 & 1.5 & 5.9 & 5.1 & 4.3 \\
\hline & 1985-1990 & 3.3 & 4.7 & 11.1 & 4.5 & 3.8 \\
\hline
\end{tabular}

The italic emphasis the period when the domestic consumption growth was the dynamic sector

a Because mark-up rates are not constant in the countries, approximate inflation or non-tradable price increase comes as follows: $\hat{p}_{\mathrm{n}}=\left(\widehat{1+m_{\mathrm{n}}}\right)+\hat{w}-\hat{q}_{\mathrm{n}}$

in the two sectors showed the same pattern. In that period, the countries' economies transformed to favor export growth. Thus, wage growth lost its importance as a stimulant for domestic consumption, and this helped inflation to decrease.

In Canada, between 1971 and 1976, the productivity growth of non-tradable goods was $1.2 \%$ higher than that of export goods. Wage rate growth was $11.0 \%$, and inflation was 7.4\%. High wage rate growth continued until 1980. However, between 1981 and 1986, the Canadian economy showed features of the Balassa-Samuelson model: the productivity growth of export goods increased significantly, to $5.4 \%$, whereas the productivity growth of non-tradable goods was $0.9 \%$. Also, inflation fell compared with previous periods, and the rate of change rate in its PPP and its currency decreased (see Table 2). 
Table 2 Change rate in the currency and PPP against the United States (annual rate, unit: \%). Source: Author's calculations. See Sect. 2.2 for the calculation of PPP. The change rates in nominal exchange rates were derived from the Federal Reserve Bank of St. Louis (exchange rate to US Dollar)

\begin{tabular}{llcc}
\hline Country & Period & $\begin{array}{l}\text { Change rate in the } \\
\text { currency against the US } \\
\text { dollar }\end{array}$ & $\begin{array}{l}\text { Change rate in PPP } \\
\text { against the United States }\end{array}$ \\
\hline Canada & $1971-1981$ & -1.8 & -3.4 \\
France & $1981-1990$ & 0.2 & -0.7 \\
& $1972-1980$ & 1.8 & -1.1 \\
Japan & $1980-1990$ & -3.8 & -4.4 \\
& $1970-1980$ & 4.4 & 3.4 \\
Netherlands & $1980-1990$ & 3.6 & 2.2 \\
& $1972-1981$ & 2.2 & 0.6 \\
Turkey & $1981-1986$ & 2.5 & 0.3 \\
& $1973-1985$ & -49.5 & -30.9 \\
& $1985-2003$ & -59.3 & -64.3 \\
United Kingdom & $19003-2011$ & -1.8 & -9.1 \\
& $1979-1984$ & -7.5 & -2.3 \\
\hline
\end{tabular}

a PPP is a hypothetical exchange rate. In a country, if the appreciation of PPP is higher than that of the nominal exchange rate, it means that the country's exchange rate is under-valued. Closest periods between the countries and the United States were used to calculate the change rate in PPP in Table 2

In France, between 1972 and 1977, the productivity growth of non-tradable goods, which was $6.0 \%$, surpassed the productivity growth of export goods. In that period, wage rate growth was $13.5 \%$-excessively high-and inflation was $9.5 \%$. However, in the period 1985-1990, wage rate growth decreased significantly. Although it is not a perfect example, France had a relative tendency toward the low-cost production model because of its decreasing wage rate growth relative to the productivity growth of non-tradable goods, and its currency moved in parallel with its PPP (see Table 2). This shows that, in the 1980s, France abandoned domestic consumption growth and decreased wage growth to better equip for export growth.

Although Japan's productivity growth of export goods was higher than the productivity growth of non-tradable goods, its wage rate growth was excessively high: approximately 13.3\% between 1970 and 1980. Thus, inflation was high; around 8.9\%. However, in following years, wage rate growth decreased significantly and the low-cost production model became dominant between 1980 and 1990; its currency remained over-valued, but it moved in parallel with its PPP (see Table 2).

The Netherlands followed domestic consumption growth until 1981, but between 1981 and 1986, wage rate growth decreased significantly to $2.3 \%$, and, most importantly, the productivity growth of export goods, which was 7.0\%, was higher than that of nontradable goods. Hence, the Netherlands' economy functioned under the low-cost production model.

Between 1968 and 1979, the United Kingdom experienced domestic consumption growth. In the period 1979-1984, this country had high wage rate growth of $9.8 \%$, surpassing the productivity growth of non-tradable goods and export goods, which were 1.0 and 4.8\%, respectively. Also, inflation was $10.2 \%$. Between 1984 and 1990, the United 
Kingdom was able to decrease its wage rate growth slightly to $7.2 \%$, and the inflation rate fell to $4.9 \%$.

In the period of 1972-1977, the United States had low productivity growth and high wage rate growth, which boosted its inflation. Between 1977 and 1982, wage rate growth increased slightly to $8.1 \%$ and inflation climbed to $9.2 \%$; unwanted conditions for a US economy experiencing low productivity growth of non-tradable goods and export goods. After 1977, the United States became an export growth country, where the productivity growth of export goods became higher than that of non-tradable goods. Between 1982 and 1985, the United States decreased its wage rate growth to reflect the productivity growth of export goods, as discussed in the Balassa-Samuelson model. During the period 1985-1990, the United States transformed to the low-cost production model by fixing its wage rate growth to the productivity growth of non-tradable goods.

In the 1970s and 1980s, the institutional forms of the developed countries discussed above also showed a parallel movement with each other. In the 1970s, these countries' manufacturing sectors maintained a large number of workers, and trade unions were stronger and more effective compared to the 1980s. As a result, industrial actions were excessive. The 1970s witnessed an important institutional change in the fixed exchange rate system, when the Bretton Woods System collapsed. In that period, in the developed countries, the production base was manufacturing and the mode of economy was more domestic consumption-oriented, except in Japan, which prioritized export policies (see Table 1). ${ }^{14}$ In the 1970s, government intervention into economies was strong. In particular, government policy was to create stability in price levels, although this was not done successfully. The role of government was to support domestic manufacturing, as agricultural production had already lost its dominant economic role in most of the developed countries. In the 1970s, the developed countries were ready to start deregulation policies mandated by neoliberalism, which in turn stimulated economic growth in the 1980s. Trade unions lost much of their power and neoliberalism became the main means of creating flexible labor and open and excessively liberal economies in most countries.

In the 1980s, a period of deregulation and globalization emerged that systematically transformed economies to embrace the free market. The institutional forms of the developed countries changed in general with deregulation policies that were necessary to curb inflation. The growth strategies of the countries came to be based on export growth. Wage growth decreased as the trade unions became weaker. Moreover, as the sectoral share of workers declined in the manufacturing sector, the trade unions lost power because of decreasing union density. Anti-inflationary policies grew in prominence. Hence, decreasing labor cost growth played a significant role in lowering inflation. The exchange rate system became more flexible. ${ }^{15}$ The countries' production was based on the export goods sector. Privatization became the policy of governments. ${ }^{16}$ Privatization

\footnotetext{
${ }^{14}$ In the Netherlands, the starting point was to develop its manufacturing sector in the 1950s with low cost production. In the 1970s, as the sectoral share of workers declined in the manufacturing sector, union density decreased. The term Dutch Disease emerged that connected the process with deindustrialization. For additional information see Thelen (2014).

${ }^{15}$ Institutional change in the exchange rate system was different for the countries which became the part of the Economic and Monetary Union of the European Union because these countries, such as France and the Netherlands, not only abandoned fixed exchange rate policies, they also followed managed exchange rate policies according to the band limit of the ERM (European Exchange Rate Mechanism) in order to adopt the euro in later periods.

16 The general trend in privatization not only influenced developed countries, but also one developing country, Turkey.
} 
transactions increased, and this also played a role in decreasing the power of trade unions. ${ }^{17}$ The mode of economy in the developed countries became excessively open and oriented to international competition. Government intervention into the economy became weaker and the role of government was more oriented to support the export goods sector than it had been in the previous period. In conclusion, the developed countries basically experienced a technological transformation in the 1970s as workers started moving into the service sector, and the countries discussed in this section completed their transformation in the 1980s to export growth policy.

\section{Structural transformation in Turkey}

Figure 2 shows the relationship between the distribution of workers among the various sectors and their movements with GDP in Turkey. As seen, there is a parallel movement of workers in the manufacturing sector and service sectors over these years, which shows a transformation away from the agricultural sector. With this transformation, GDP and GDP per capita increased. For instance, GDP was 62.2 billion US dollars in 1975 and 800 billion US dollars in 2014. Although GDP per capita remained below that of higher income countries, it was 1555 US dollars in 1975 and 10,404 US dollars in $2014 .{ }^{18}$ The figure does not show a downward inclination in the relationship between the share of workers in the manufacturing sector and GDP, and the level of GDP per capita, which remains lower than in developed countries, implying that Turkey is still a developing country and keeps its dynamism in structural transformation via the manufacturing sector. Thus, the manufacturing sector's share of workers shows a steadily increasing trend. In 1923, the agricultural sector's share of workers was $89.9 \%$, and in 1950 , it was $84.3 \%$, whereas that of the manufacturing sector was $4.3 \%$ in 1923 and $8.6 \%$ in 1950. In 2014, the distribution of workers showed a different configuration: $21,27.9$ and $51 \%$ in the agricultural, manufacturing and service sectors, respectively.

Table 3 shows the correlation between the parameters discussed in Fig. 2. As seen, the proportion of workers in the agricultural sector was negatively correlated with real GDP and the distribution of workers between the manufacturing and service sectors. The important point is to note that two other parameters, the manufacturing and service sectors, are positively correlated with real GDP and with each other. This shows that worker distribution has been increasing both in the manufacturing and service sectors. Moreover, sectoral shares of value-added and production in these two sectors, and GDP showed a parallel movement as discussed in Fig. 2 (see Figs. 7, 8). For instance, between 1970 and 2015, the value-added share of the agriculture sector decreased on average by $2.3 \%$, and those of the manufacturing and service sectors increased on average by 0.8 and $0.3 \%$, respectively. In addition, between 1923 and 2014, the production share of the agricultural sector decreased on average by $1.5 \%$, whereas those of the manufacturing and agricultural sectors increased on average by 1.2 and $0.7 \%$, respectively. Furthermore, the manufacturing sector's share in export goods compared with that of the agricultural sector rose in parallel with GDP (see Fig. 5). The important point is to see here that the

\footnotetext{
${ }^{17}$ Deregulation policies in the 1980s damaged the power of trade unions to conduct industrial actions in the developed countries in general. For additional information about Japan's privatization and industrial action see (Nakakubo 2015DP per capita is derived from Ministry of Development's report (Economic and Social Indicators between 1950 and 2014).
} 


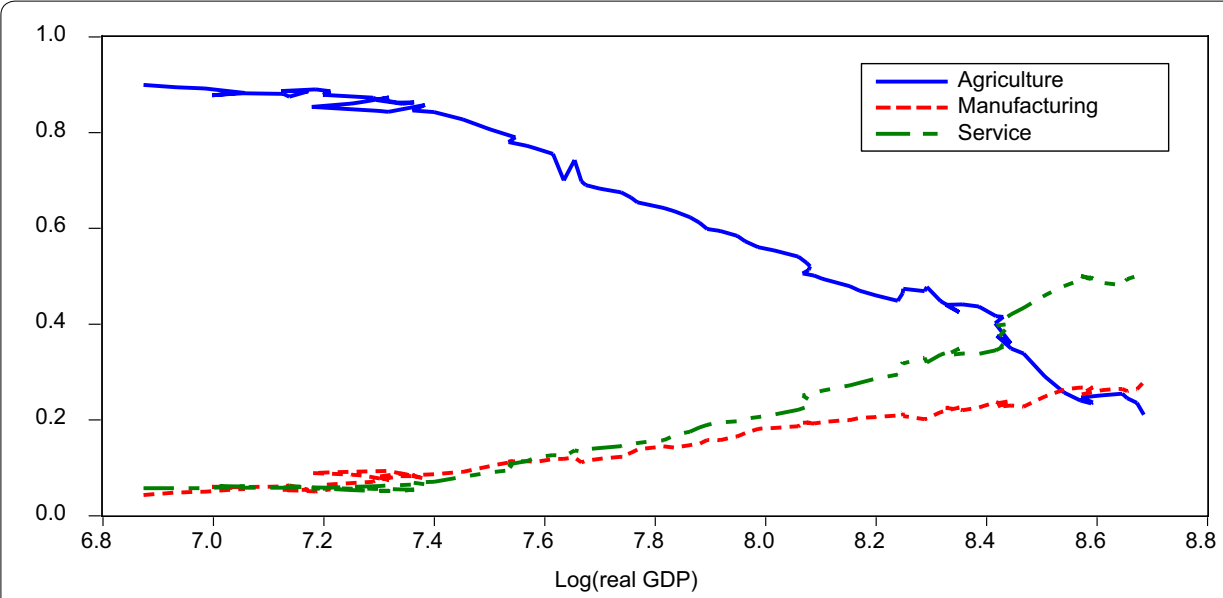

Fig. 2 Sectoral shares of workers in the three sectors, and GDP (annually, 1923-2014). Note: Real GDP is used for sectoral comparison, because it has a greater time span and it is favorable to do time series analysis with worker distribution. The manufacturing sector is the activities not categorized within the agricultural and service sector. GDP is expressed as US dollar. Source: Author's calculation. Employment data were derived from TurkStat (employed persons by kind of economic activity). GDP is derived from Ministry of Development's report (Economic and Social Indicators between 1950 and 2014) and calculated with exchange rate of 1998 to find real GDP in US dollars $(1998=100)$

Table 3 Correlation between sectoral shares of workers and GDP (annually, 1923-2014). Source: Author's calculation. See Fig. 2

\begin{tabular}{lcccr}
\hline & Log (real GDP) & Agriculture & Manufacturing & Service \\
\hline Log (real GDP) & 1.0000 & -0.9846 & 0.9915 & 0.9593 \\
Agriculture & -0.9846 & 1.0000 & -0.9905 & -0.9850 \\
Manufacturing & 0.9915 & -0.9905 & 1.000 & 0.9681 \\
Service & 0.9593 & -0.9850 & 0.9681 & 1.000 \\
\hline
\end{tabular}

Turkish economy is still on its development path as the manufacturing sector still does not have a clear downward inclination.

The structural transformation over time created a different configuration in forms of wage growth, and the ratio of export to import in these sectors (see Tables 11, 12). In the period of 1973-1985, wage growth in the agricultural sector was closer to inflation and to those of other sectors, but over the years, wage growth in the manufacturing and service sectors increased more than in the agricultural sector. In the period 2003-2009, inflation was $11.5 \%$, and wage growth was $10.8 \%$ in the agricultural sector but $12.7 \%$ in manufacturing and $15.6 \%$ in the service sector. In addition, in 1973, the ratio of export to import was 17.2 in the agricultural sector and 0.24 in the manufacturing sector. As industrialization became dominant and agriculture lost its importance, the ratio decreased to 0.82 in the agricultural sector, but it increased to 0.73 in the manufacturing sector in 2016.

\subsection{Agricultural growth and institutional factors in the period 1950-1962}

The Republic of Turkey was found by a military commander, Mustafa Kemal Atatürk, and from 1923 to the mid-1940s, the Turkish economy was developed under the state policies of a single political party, the Republican People's Party. The Turkish economy 
Table 4 Productivity growth in agricultural, manufacturing, service, and all sectors (annual rate, unit: \%). Source: Author's calculation. Employment data was derived from TurkStat (employed persons by type of economic activity). Productivity growth was calculated by deriving sectoral data from the Ministry of Development's report (Economic and Social Indicators between 1923 and 2014) and calculated with real outputs. Inflation was derived from TurkStat (consumer price). The inflation data between 1923 and 1939 replaced with wholesale price index

\begin{tabular}{lccccc}
\hline Period & Agriculture & Manufacturing & Service & All sectors & Inflation \\
\hline $1923-1931$ & 8.3 & 3.9 & 3.8 & 6.4 & -3.3 \\
$1931-1939$ & 6.2 & 0.7 & 4.5 & 5.0 & 2.3 \\
$1939-1945$ & -9.4 & -8.8 & -6.5 & -7.7 & 19.7 \\
$1945-1950$ & 4.2 & 1.9 & 1.1 & 4.6 & 0.3 \\
$1950-1956$ & 4.3 & 2.2 & -4.6 & 4.1 & 4.2 \\
$1956-1962$ & 2.4 & 1.8 & 0.3 & 2.9 & 11.8 \\
$1962-1973$ & 1.4 & 3.8 & 1.8 & 3.9 & 8.2 \\
\hline
\end{tabular}

The italic emphasis the period when the manufacturing sector became the dynamic sector

had an agricultural growth regime from 1923 to 1962, as seen on Table 4, where productivity growth in the agriculture sector was greater than those of other sectors. The turning point for industrialization that supported the manufacturing sector emerged in the 1950s. After the Democrat Party was elected in the 1950s, it followed liberal policies in the Turkish economy, and thus opened the economy for international trade and supported private industries in developing its agricultural sector. Hence, the agricultural production became dominant growth strategy as a flash point for mechanization and industrialization in the economic development of Turkey in the 1950s.

Table 4 shows that the productivity growth of the agricultural sector was larger than that of the manufacturing sector, and inflation was very low between 1950 and 1956. That indicates the economy was growing through agricultural production. The productivity growth of the agricultural sector was $4.3 \%$, whereas that of the manufacturing sector was $2.2 \%$. Inflation stood at $4.2 \%$-one of the lowest rates in Turkish economic history. In that period, agricultural production was dominant and it was the main contributor to economic growth. The contribution of agricultural production to all sector's productivity growth can be seen clearly: $4.1 \%$, closer to that of agriculture. In the period 1956-1962, Turkey experienced an economic crisis which decreased its performance in terms of productivity growth. The productivity growth of the agricultural sector was $2.4 \%$, and that of the manufacturing sector, $1.8 \%$. Productivity growth of all sectors remained at $2.9 \%$, while productivity growth of the service sector was just $0.3 \%$. In that period, falling productivity growth and an economic crisis boosted inflation, which increased to $11.8 \%$. Low export growth caused a trade deficit and deepened Turkey's problems into a full-blown economic crisis in the mid-1950s. For instance, in 1946, the ratio of export to import was 1.8, but this ratio decreased to 0.63 in 1955. Between 1950 and 1953 , imports increased by approximately $18.3 \%$ and exports by $12.6 \%$. The peak years were 1951 and 1952, when imports rose by 40.8 and $38.3 \%$, respectively. ${ }^{19}$

\footnotetext{
${ }^{19}$ Source: Turkstat (foreign trade by years).
} 


\subsubsection{Institutional factors in the period of agricultural growth}

One of the reasons for the high productivity of the agricultural sector compared with other sectors between 1950 and 1956 was government policies to invest in agriculture and produce for global demand, which brought technological changes to the Turkish economy, when the first imports of high-tech transportation and machines were demanded, and helped develop mass production in subsequent years. This transformation was simultaneously followed by institutional changes based on liberal policies aimed at creating a non-restricted economy shaped by state-led policies to ease the import and export of goods in international trade. Increasing imports in the Turkish economy necessarily gave way to the needs for exports as well. Therefore, as a country, which did not have enough industrial development, agriculture gained prominence in economic activities. The increasing amount of machinery lessened demand for labor in the agricultural sector, but created a need for physical power in manufactures. Hence, labor was attracted by developing manufactures through migration from rural areas.

For the mode of employment, as seen on Fig. 2, the sectoral share of workers in the manufacturing sector increased significantly. For instance, whereas the number of workers in the agricultural sector increased on average by $0.9 \%$, it was $5.6 \%$ in the manufacturing sector between 1950 and 1962. However, during that period, the number of workers in manufacturing constituted a small proportion of the total employed labor force, which shows that the mode of employment was based on the agricultural sector. Whereas the percentage of agricultural workers was $84.3 \%$, that of manufacturing workers was only $8.6 \%$ of the total number of employed people in 1950 . Although the number of agricultural workers increased consistently until 1990, as a percentage of employed people, it decreased.

In this period, Turkey did not have institutionalized trade unions. The bulk of labor consisted of agricultural workers during the 1950s, and economic growth was based on agricultural production between 1950 and 1962. Turkey was able to develop and establish private industries and increase production by agricultural land development. The lack of trade unions in the Turkish economy did not influence inflation because wage rate growth did not translate into pressure for production and government policies. Inflation was very low between 1923 and 1956, except during the Second World War, which could be explained by high productivity growth in the agricultural sector and low labor pressure for wage increases. ${ }^{20}$ The relatively lower cost production compared with following years, and open economic policies, supported demand for Turkish agricultural products in international trade. However, between 1956 and 1962, productivity growth decreased; thus, inflation climbed significantly, to $11.8 \%$ (Table 4). ${ }^{21}$

In that period of 1950s, there was a fixed exchange rate system based on the US dollar. The Government exerted excessive influence on the CBRT to restrict fluctuations in the exchange rate. The inflation rate, which has been one of basic issues in the Turkish economy, did not cause great problems in the early 1950s.

\footnotetext{
${ }^{20}$ Although Turkey did not enter the Second World War, it was affected negatively. Productivity growth rates decreased significantly and inflation rose dramatically between 1939 and 1945 (see Table 4).

${ }^{21}$ It is generally accepted that Korean War between 1950 and 1953 was one of the reasons that increased demand for agricultural products of Turkey.
} 
Although the economy was shaped by liberal economic policies, with non-unionized agricultural and manufacturing workers, who did not have a basic right to strike, wage growth policy was implemented by government intervention. Nevertheless, decreasing productivity growth and a high trade deficit problem led to significant devaluations in the lira, as seen in Fig. 3. In the late 1950s, the lira depreciated by approximately $73.9 \%$, and in 1960 , it depreciated by approximately $84.8 \%$. Although, owing to non-institutionalized trade unions, wage rate growth did not constitute serious pressure on inflation, the increasing trade deficit, the long period of fixed exchange rates, and compounding economic problems related to high costs of production and inflation gave way to devaluations.

The base of production was developed around agricultural production and that shaped Turkey's configuration in international trade. Turkey could not establish its manufacturing industries sufficiently to produce durable goods for the needs of the middle class or to export. However, agricultural base production gave way to increasing development in manufacturing industries over the years. In that period, Turkey had open economic policies and for the first time experienced a high trade deficit, which became a chronic problem in subsequent periods (see Fig. 4). Increasing international demand for agricultural products became a reason to follow open import and export policies. The government's open economic policies involved supporting the growth of private industries alongside public industries. Thus, the role of private industries in production increased significantly. As seen in Table 5 the open economic policies and the effect of promoting private industries is clear. In the period of 1950-1960, the number of private

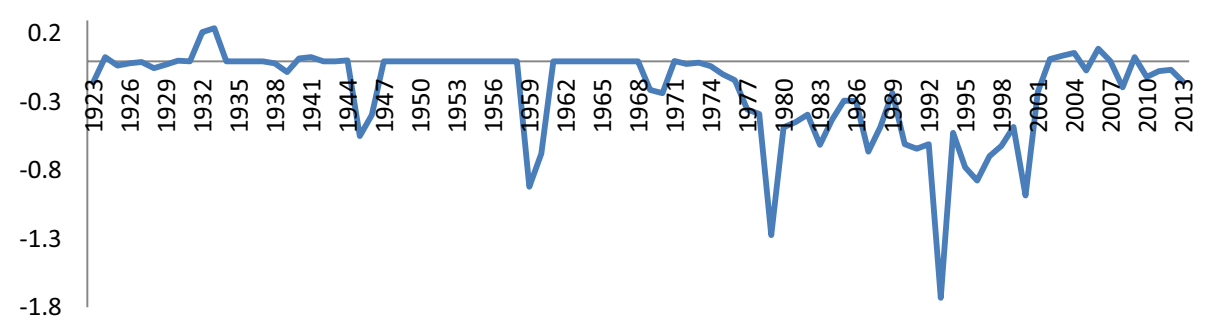

Fig. 3 Change rate in the lira (annual rate, 1923-2013). Source: Author's calculation. The change rates in the lira were derived from TurkStat (Statistical indicators 1923-2013)

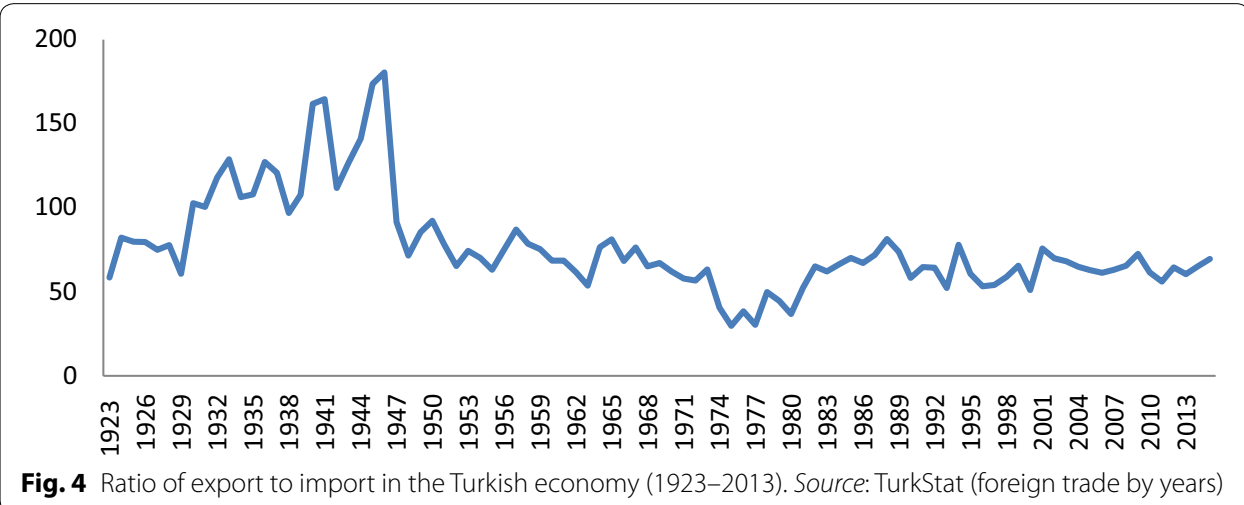


Table 5 Change rate in number of private and public manufactures (annual rate, unit: \%). Source: Author's calculations. Manufacturing industries of public and private sectors were derived from TurkStat

\begin{tabular}{lll}
\hline Category & $\mathbf{1 9 5 0 - 1 9 6 0}$ & $\mathbf{1 9 6 0 - 1 9 7 0}$ \\
\hline Private manufactures & 9.4 & 1.3 \\
Public manufactures & 7.6 & 4.4 \\
\hline
\end{tabular}

manufactures increased by approximately $9.4 \%$, higher than that of public manufactures, which increased by $7.6 \%$.

In the early 1950s, the number of industries increased significantly, not only because of demand for agricultural products, but also because of the mode of economy was based on open and liberal policies. Although in following years deepening economic instability slowed growth in the number of industries, the Turkish economy was able in relative terms to develop its industrial production base to follow import substitution industrialization policies in an attempt to reduce economic problems which remained from the period of agricultural growth. ${ }^{22}$ In other words, the failed attempt at an open economy provided an opportunity for industrialization. Although private industries became an important part of the economy, privatizations were not visible and not yet institutionalized in the Turkish economy. The significance of private industries declined in the 1960s. Closed and protected economic policies in that period caused a slow increase in the number of private manufactures by $1.3 \%$, whereas the number of public manufactures increased by $4.4 \%$, (see Table 5 ). In particular, in the early $1960 \mathrm{~s}$, the rate of change in the number of private manufactures decreased by $34.9 \%$ in Turkey.

The role of government was shaped by open and liberal economic policies. The economy, which lacked trade unions and social movements, enabled the government to implement liberal policies with ease. Thus, government intervention in the market was distinctive and strong. The role of government was based on agricultural growth because government promotion of agricultural production that was the only economic means available in the country for the increase of export goods in the 1950s. Moreover, Turkey did not have a serious problem with inflation in the beginning of the 1950s, and was able to create high productivity growth, which made it relatively successful. Nevertheless, agricultural production became problematic in subsequent years due to low productivity growth caused by decreasing demand. This forced the country to implement devaluations in order to increase its competitiveness and cover its trade deficit. These problems could not be eliminated and continued in subsequent years. The government's liberal policies were criticized by the military and its veterans after productivity growth decreased and the country encountered high inflation and a long-lasting trade deficit problem. The democratic government failed to produce effective policies to regulate the economy. Finally, the government lost its function in the end of 1950s, and, following the military coup, the prime minister was executed and a new government instituted regulation policies that turned Turkey into a closed and protected economy similar to those of the developed countries, promoting domestic consumption until the 1980s.

${ }^{22}$ In the period of 1950-1956, the number of industries increased by $9.9 \%$, and in the period of 1956-1962, increase was $0.3 \%$. Source: Author's calculation. Data was derived from TurkStat (manufacturing industry, total). 


\subsubsection{The crisis of the agricultural growth regime}

In the beginning of the 1950s, Turkey was able to stimulate its agricultural productivity growth, which was the dynamic for low inflation, a stable exchange rate and industrial development. Between 1950 and 1953, the productivity growth of the agricultural sector was $10.2 \%$, whereas that of the manufacturing sector was $3.2 \%$. However, toward the end of the 1950s, Turkey encountered macroeconomic problems that deepened instability in the economy and led to essential reform measures taken in 1958. These problems occurred because of a high trade deficit and inflation following falling productivity growth. To cut demand for imports of goods and accelerate the export of goods, the lira depreciated significantly against the US dollar. Rising inflation became one of the reasons for the economic crisis at the end of the 1950s. To counter high inflation, an attempt was made to control monetary expansion by preventing the CBRT from financing public enterprises by printing money. These reforms failed to work as expected that followed with a structural change in the economy by leading to import substitution industrialization by 5 -year development plans.

In the beginning of the 1960s, following the military coup against the Democrat Party, new legislation was enacted. Turkey began implementing planning programs to improve its industrial production using import substitution industrialization strategies. Thus, agricultural production lost its importance and manufacturing production became the dominant base of the Turkish economy. In the period of 1962-1973, the productivity growth of the agricultural sector was $1.4 \%$ lower than that of the manufacturing sector, which was $3.8 \%$. Furthermore, the productivity growth of the service sector was $1.8 \%$, and all sectors' productivity growth was $3.9 \%$ closer with that of the manufacturing sector. The increase in productivity growth in the manufacturing sector was larger than that of the agricultural sector highlights important technological changes in the Turkish economy, and a growing capacity in product manufacturing (see Table 4).

\subsection{Domestic consumption growth and institutional factors in the period 1962-1985}

The main aim of import substitution industrialization is to achieve economic self-sufficiency by protecting infant industries until they reach a technological level whence they can compete in international trade. By this means, domestic industries grow and become more self-sufficient. This type of industrialization was implemented in Turkey using a series of 5-year development plans. The government implemented tariffs and quotas to protect domestic industries and give time and support for their development. In the 1960s and 1970s, governments stimulated investment to reach the objectives of their development plans. Some important industries such as the automobile, machinery, chemical and chemical products and electrical and optical equipment industries were established and upgraded in this period under the 5-year plans. Finally, the manufacturing sector became the base of Turkish exports from the 1980s onward.

Compared with developed countries, Turkey had highest ULC growth in both nontradable goods and export goods. In line with other countries, because of closed economic policies, Turkey pursued domestic consumption growth. Between 1973 and 1985, wage rate growth was $34.2 \%$, and the productivity growth of non-tradable goods was $3.8 \%$ higher than that of export goods, which was $2.0 \%$. Moreover, Turkey's inflation rate was greater than that of other countries. During the period 1985-2003, the most 
important point in Turkey contrary to other countries, wage rate growth increased significantly, to $66.2 \%$, and inflation climbed to $63.5 \%$ (see Table 1). Although Turkey was able to decrease wage rate growth to $11.2 \%$ between 2003 and 2011, it remained higher than the productivity growth of export goods and non-tradable goods. Hence, Turkey came under the dominance of the over-valued currency model due to its over-valued currency and high-cost production.

An analysis of Turkey's macroeconomic factors showed that Turkey had parallel macroeconomic factors with the developed countries in the 1970s as a protected economy. In the 1980s, in contrast to the developed countries, its wage rate growth was stimulated and its inflation boosted. However, Turkey became an export growth country after 1985, which shows that there were contradictions in its macroeconomic and institutional factors, which were not designed according to economic policies in these periods. Turkey could not create institutional complementarity to satisfy export growth under free and open economic policies designed to increase its competitiveness. Turkey should have at least decreased its wage rate growth to match the productivity growth of export goods for institutional complementarity that did not break international competition and could have decreased ULC growth in Turkey.

The domestic consumption growth was supported through forcible regulations in Turkey. To conduct the first 5-year development plans for developing basic and intermediate goods industries in order to reach the desired level of industrial developments in specific, planned years, a state planning organization was established in September, 1960 to assist the government. The institutional factors of the 1950s evolved alongside increasing manufacturing production, and an international context based on the idea of the developed capitalist economies employing government intervention in the economy to control prices and incomes, and to support the rights of workers and trade unions through welfare policies. Nevertheless, unfavorable macroeconomic factors prevented Turkey having a stable growth model. Turkey had similar problems to the developed countries, such as inflation and high ULC.

\subsubsection{Institutional factors in the period of domestic consumption growth}

During the period 1962-1985, wage-labor relations changed significantly and new modes of employment emerged. Although agriculture kept the bulk of the labor force, the importance of manufacturing workers increased for import substitution industrialization. Thus, trade unions came into prominence, and gained legal ground owing to growing manufacturing production and demand for workers. The government postulated the idea that manufacturing production was more important than agricultural production as manufactures contributed more to the economy in terms of export than agriculture could. This prompted an increase in the number of manufacturing industries, which attracted workers in the cities and agricultural workers from rural areas. Nevertheless, agriculture remained an important part of the economy. The mode of employment was thus based on both agricultural and manufacturing workers.

After the technological change from agricultural production to manufacturing production, Turkey created a legal status for trade unions. Growing industries furnished a need for the establishment of decent working conditions and grounds for social rights for workers; hence, collective bargaining became more of an issue in income policy. 
Table 6 Strikes and lock-outs in Turkey. Source: Data were derived from Ministry of Labour and Social Security (in Turkish, grev ve lokavt uygulamaları)

\begin{tabular}{lcccc}
\hline Year & Number of strikes & $\begin{array}{l}\text { Workdays lost } \\
\text { to strikes }\end{array}$ & $\begin{array}{l}\text { Number of lock- } \\
\text { outs }\end{array}$ & $\begin{array}{l}\text { Workdays lost to lock- } \\
\text { outs }\end{array}$ \\
\hline 1963 & 8 & 19.739 & 0 & 0 \\
1970 & 72 & 220.189 & 4 & 98.229 \\
1975 & 116 & 668.797 & 7 & 67.949 \\
1980 & 220 & 1.303 .253 & 21 & 682.843 \\
1987 & 307 & 1.961 .940 & 221 & 484.572 \\
1990 & 458 & 3.466 .550 & 41 & 1.188 .091 \\
1995 & 120 & 4.838 .241 & 5 & 162.512 \\
2000 & 52 & 368.475 & 2 & 32.760 \\
2012 & 8 & 36.073 & 0 & 0 \\
\hline
\end{tabular}

During the planning periods of the 1960s, collective bargaining became for the first time an aspect of manufacturing production, and legally recognized trade unions were able to conduct strikes and organize other industrial actions. After gaining basic rights, the trade unions began to flex their muscles in the early 1960s. Eight strikes occurred in 1963, and this number increased dramatically in following years (see Table 6). ${ }^{23}$ Trade unions were influenced by radical left wing movements, in particular, the communism of the Soviet Union, and led to widespread political unrest in Turkey. Economic problems, combined with labor and political actions, devastated efficiency in production, with many workdays lost in industries in the 1970s. The increasing number of strikes and lock-outs inevitably damaged the Turkish economy and its industrial production. The pressure of the trade unions for wage increases led to high inflation, which was also compounded by the government's monetary expansion to finance public industries by the CBRT printing money without counterpart. The government accepted minimum wage policies in the mid-1970s, based not on collective bargaining, but on workers' own basic rights. In this period, more than $50 \%$ of workers were low-skilled, which means the minimum wage covered a large area in the economy. Hence, the institutional changes in the 1960s made trade unions and social movements stronger, but these reforms delayed new institutional changes in the 1970s and 1980s, namely the deregulation policies demanded by neoliberalism, and influenced the economic development and competitive position of Turkey in forthcoming periods.

The exchange rate system was a fixed system. However, the lira experienced significant devaluations caused by the high ULC growth of export goods because it increased dramatically while productivity growth remained low. For instance, the ULC growth of export goods was $32.2 \%$ in the period 1973-1985 (see Table 1). In that period, due to high production costs, the Turkish economy was unable to compete and eliminate its trade deficit problem. High wage rate growth over the productivity growth of nontradable goods caused destructive inflation, and high ULC growth of export goods became a major factor in deepening pressure on the lira and following its depreciations. In that period, the government intervened heavily in the policy of the CBRT over the exchange rate. Furthermore, high inflation, the high ULC growth of export goods and a

${ }^{23}$ In Turkish, Grev ve Lokavt uygulamaları (http://www.csgb.gov.tr/csgbPortal/csgb.portal?page=grevlokavt) accessed on January 6, 2016 
compounding trade deficit strongly influenced the decisions of the CBRT, which engineered successive devaluations. Thus, the lira became under-valued between 1973 and 1985 in long-term (see Table 2).

The production base changed significantly as the economy evolved from the agricultural to the manufacturing sector. This technological change led to a large increase in productivity in the first years of the 1960s. For instance, between 1962 and 1964, the productivity growth of the manufacturing sector was $15.5 \%$, whereas that of the agricultural sector was $6.1 \%$, and inflation was $2.5 \%$. However, unlike in previous periods, the manufacturing sector was protected owing to new institutional changes. A significant amount of industry remained in the public sector, under government control. Hence, the income policies of these industries were exposed to industrial action and the populist aims of the government. That means that the formulation of wage policies was based on individual interests rather than economic conditions.

The institutional changes led to a protected and closed economy. Privatization was not institutionalized and was not a matter for political discussion. The influence of public industries around the country was distinctive. Import substitution industrialization was the dominant strategy, aimed at developing domestic industries via government policies.

The mode of economy was shaped through protectionism, via taxes and tariffs and closed economic ideas based on domestic manufacture-a change from the open and liberal formation of the previous period to a protected and closed formation. This was an important complementarity which combined institutional factors; a potential basis for a consistent economy. For instance, protected industrial and closed economic policies as a mode of economy were important signs of institutional complementarity for the promotion of domestic consumption.

The government's intervention in the economy was excessive, and the role of government was important for promoting domestic manufacturing, but although the importance of manufacturing increased, international insertion was based on the export of both manufacturing and agricultural products in the 1960s and 1970s. Between 1960 and 1980, developing manufacturing production made Turkey more integrated into the global economy because of increasing interaction between countries based on imports and exports. However, in the 1970s, the ratio of exports to imports fell to its lowest point, approximately $30 \%$. Figure 4 shows this significant decrease in the ratio. In the 1950s, developments for industrialization under agricultural growth increased the import of goods, which, combined with the liberal policies of the government, resulted in a relatively open and unprotected economy. In the 1970s, a trade deficit was stimulated, inflation increased and Turkey experienced a new economic crisis. This problem was mainly caused in wage-labor relations related to income policies, which boosted inflation and ULC in the economy. Reforms to solve these economic problems could not be implemented efficiently and the economic decisions that had to be taken in the parliament remained slow. Necessary institutional changes did not emerge in time, and Turkey could not respond adequately to the global economic situation. The institutional changes that were developed in the 1960s and 1970s were not satisfactory for the Turkish economy because they brought excessive protection for employees, based as they were on welfare policies and shaped overwhelmingly by domestic consumption growth. These changes generated inconsistencies and caused deepening and chronic problems. 
Moreover, this situation prevented institutional complementarity in the macroeconomic base and caused path dependency in subsequent periods.

\subsubsection{The crisis of domestic consumption growth regime}

Although the government supported domestic manufacture, due to the lack of complementarity between macroeconomic and institutional factors, industrial policies contributed nothing to the alleviation of problems in the Turkish economy, as had been expected in the 1960s, and this dragged the country into a devastating economic and political crisis at the end of 1970s. Turkey's economic reforms were slowed down by political turmoil and social movements. Shaky coalition governments could not produce necessary economic reforms, and this deepened the country's economic problems. Moreover, by decisions in January 24, 1980, the government imposed less restriction on imports of goods, supported export by promotions and implemented devaluations in the lira as a preparation for export growth strategies. ${ }^{24}$ The decisions taken in the $1980 \mathrm{~s}$ were a result of a program supported by the IMF. The reforms were necessary to cut monetary expansion and aimed to reduce the power of trade unions, to increase privatization and decrease the influence of public industries in the market. Furthermore, Turkey decreased its support for the agricultural sector while promoting manufacturing production in an attempt to stimulate exports. This transformation, however, remained slow. In the beginning of 1980s, political and economic problems led to another military coup. The deregulation policies in the economy continued and these policies were relatively supported in following years. The trade union legislation that was established in the 1960s made it hard to achieve flexibility of labor without political unrest. In the 1980s, although trade unions lost a measure of their power, public industries still dominated the economy. Hence, the change to a free market economy remained largely incomplete. Additionally, expected privatizations of the largest public industries met with protests and other pressures, and could not be institutionalized until the mid-1990s when Turkey established an institution for the support of foreign direct investment into the public industries.

Turkey began increasing its economic reforms to promote export growth in the economy. The export growth strategies began taking root after 1985 after a new democratic government took power. In consequence, the productivity growth of export goods increased more than that of non-tradable goods. Therefore, since the mid-1980s, export growth has become a distinctive feature of the Turkish economy. However, institutional changes remained uncompleted and did not show complementarity with macroeconomic factors in parallel with the developed countries.

\subsection{Transformation to export growth in the period 1985-2003}

During the period 1985-2003, Turkey was unable to implement strict institutional changes, and in 2000-2001 met with a severe economic crisis. For a long period of time, it suffered from high inflation, wage growth and unstable exchange rate. In other words, although Turkey gained a new production base for export growth from technological change, it was unable to develop new solutions, and this caused conflict between

\footnotetext{
${ }^{24}$ In particular, after the collapse of the Bretton Woods System, free market economy and exchange rate systems became important components of institutional changes imposed by the IMF.
} 
macroeconomic and institutional factors. Hence, this period was basically one of transformation, when Turkey began seriously implementing deregulation policies. In the transformation period, Turkey failed to implement a number of institutional changes to prepare the economy for export growth, whereas the developed countries discussed in Table 1 were able to do that by decreasing their ULC growth via deregulation policies. The wage rate growth was $66.2 \%$ greater than the productivity growth rates and inflation increased to $63.5 \%$. The worst condition was that ULC growth of export goods in the Turkish economy increased from 32.2 to $60.9 \%$ between the periods of 1973-1985 and 1985-2003. There was a conflict between the new growth regime based on export and old institutional changes shaped for domestic consumption growth, and this deepened the lack of complementarity in the economy. In other words, although the country began pursuing export growth with open economic policies and relatively deregulatory policies, institutional factors remained largely unchanged. For instance, the trade unions maintained their position, privatizations were not implemented to any great extent and the government continued its populist income policies. Thus, in the period 2000-2001, the inconsistency between the new growth regime and old institutional factors caused the biggest economic crisis. This problem manifested itself because of uncompleted regulations that should have created institutional complementarity and eliminated path dependency remained from pre-1980s.

Compared with previous periods, the mode of employment changed visibly. The role of manufacturing workers became dominant in the economy and exports of manufacturing products in total export passed those of agricultural products in the early 1980s. The relatively developed manufacturing industries in the closed and protected economic period began to compete in international trade. However, the position of the trade unions remained strong. Regarding wage-labor relations, the pressure of trade unions on government policies increased significantly. Spurred by expectations of institutional change and hardening economic conditions compared with the previous periods, the number of strikes peaked (see Table 6). Strikes and lock-outs increased more rapidly than in the 1960s and 1970s. Workdays lost to these industrial actions by both trade unions and employer unions reached their highest level in the 1980s. In addition, wage rate growth increased significantly more than in previous periods. This economic unrest made Turkey follow a different path than the developed countries in the 1980s.

Turkey attempted to implement a number of institutional changes to eliminate the increasing pressure from workers; changes that influenced the employment structure of the manufacturing sector. Neoliberal policies combined with high productivity growth of exports goods and that created new strategies of Turkey according to the new growth regime. Although export growth should have been associated with lower cost production in international trade to maximize gain, Turkey experienced the highest ULC growth of export goods in its history, which wrecked the fixed exchange rate system and led to devaluations. Thus, in this period, the exchange rate system was transformed from a fixed to a managed system. Nevertheless, that did not stop devaluations in the lira. Contrary to the previous period, the lira became an excessively inconsistent and overvalued currency. The change rate in the lira against the US dollar was $-59.3 \%$, whereas that of PPP was $-64.3 \%$ in the period 1985-2003 (see Table 2). The lack of institutional complementarity between macroeconomic and institutional factors for stable export 
growth carried with it the problem of high inflation and trade deficit to the following period because Turkey continued to experience high production costs and a massively over-valued currency, which placed it squarely in the over-valued currency model.

Production base strategies were tailored to export goods sector. To eliminate problems that emerged in the period of 1962-1985, government sponsored export growth became the dominant policy. In the 1980s, Turkey relaxed its protectionist policies and attempted to implement neoliberal policies. Political density related to international insertion significantly increased the importance of export goods sector. Manufacturing products surpassed agricultural products in the share of total exports in the early 1980s. This shows that although the closed economic policies were inefficient, they helped domestic industries to reach a level for export growth that reflected on manufacturing production as technological change. As seen in Fig. 5, before 1980, the share of manufacturing products in total exports was lower than that of agricultural products. However, manufacturing goods became the main export products in the 1980s. In 1963, the agricultural sector's share was $77.2 \%$ and the manufacturing sector's was $22.8 \%$. In 1981, this structure changed significantly. The agricultural sector's share was $46.2 \%$ and that of the manufacturing sector was $53.0 \%$. In the 2010s, the contribution of the agricultural sector to export declined significantly. In 2014, the agricultural sector's share was $3.8 \%$, and the manufacturing sector's share was $95.5 \%$. In addition, technological change became clear with high productivity growth of export goods, around 5.3\%, surpassing that of nontradable goods, which was 3.0\%, between 1985 and 2003 (see Table 1).

In Turkey, the first deregulation rules for privatization were produced in 1984, but transactions remained low compared with that of the 2000s. This was due to uncompleted reforms and slow transformation. Turkey enacted the necessary legislation very late and in practice was unable to implement deregulation policies properly until the early 2000s. Thus, the trade unions, which were banned after the military coup in the early 1980s, organized strikes until Turkey created institutional changes under new

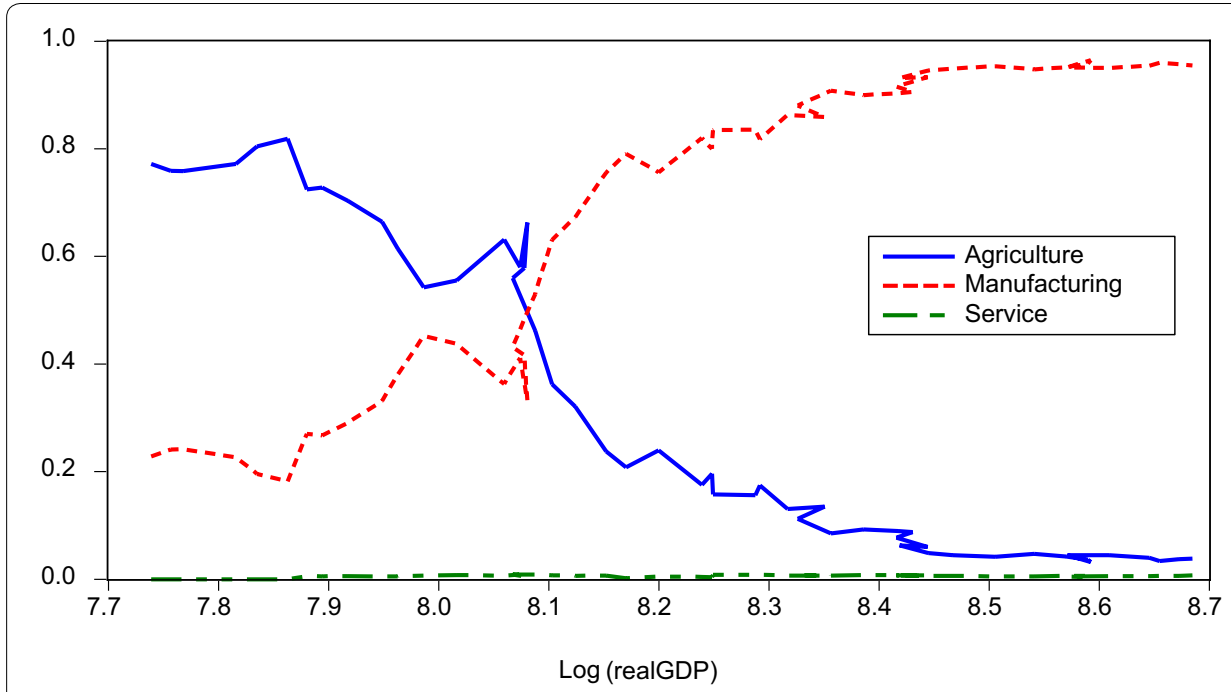

Fig. 5 Sectoral shares of exported products, and GDP in Turkey (annually, 1963-2014). Source: Author's calculations. Data were derived from TurkStat (exports by economic activity). For GDP information see Fig. 2 
legislation and implementations. One of the reasons for the increase in strikes, lock-outs and lost workdays was slow deregulation policies. Turkey developed new institutional changes to stimulate and create a ground for privatizations. With that aim, the Privatization Board of Turkey was established in 1994; hence, privatization became institutionalized. After this important institutional change, the power of trade unions became weaker, and the number of strikes and lock-outs gradually decreased (see Table 6).

In the 1980s and 1990s, attempts were made to ground the mode of economy on open economic policies. Although the Turkish economy was shaped by export growth, institutional changes lagged behind the technological changes that had shaped the new growth regime. Thus, because of high-cost production in export goods sector and an over-valued currency, the trade deficit continued to be a problem. Therefore, it can be said that although Turkey had been under an export growth regime, it could not create a strong competitive economy shaped by institutional complementarity between macroeconomic and institutional factors.

The role of government in implementing the institutional changes necessary for deregulation was central: government economic intervention remained strong. To eliminate the problem of the trade deficit, the government supported export industries and implemented open economic policies that were capable of attracting an important amount of foreign direct investment. However, without institutional changes to reform wagelabor relations in the light of macroeconomic factors, government action did not bring satisfactory results. In the mid-1980s, the government failed to produce the substantial reforms needed for the promotion of export growth. Privatizations remained few; the largest public industries could not be privatized. The required investments did not flow to Turkey, and increasing inflation and the volatility of the lira generated speculation, which combined with an over-valued currency and low competitiveness. ULC growth increased significantly, inflation rose, and the exchange rate continued experiencing devaluations. Finally, Turkey faced a structural economic crisis. In effect, the transformation process, based as it was on export growth but lacking necessary institutional changes generated a new economic collapse in 2000-2001: a foreign currency shortage, itself a result of Turkey's untenable competitive position, collapsed the managed exchange rate system and led to a large depreciation in the currency, government debt and an economy crushed under high inflation.

\subsubsection{Economic crisis in 2000-2001 and new institutional changes}

In the 2000s, while the mode of employment was based on manufacturing workers, demonstrations and strikes by trade unions decreased significantly (see Table 6). During the period of strict deregulation policies, although trade unions tried to resist privatization by industrial action, which significantly increased lost workdays, the privatization process continued. The period witnessed a weakening of the trade unions, although numbers of manufacturing workers kept increasing. The sectoral share of manufacturing workers rose from 22.7 to $27.9 \%$ between 2003 and 2014. In the same period, that of agricultural workers decreased from 33.9 to $21.1 \%$. The increase in the sectoral share of manufacturing workers was greater. The sectoral shares of manufacturing and service 
workers rose on average by 1.9 and $1.5 \%$, respectively. ${ }^{25}$ This process was reflected in the ULC growth of export goods, which diminished considerably, supported export goods sector and attracted foreign direct investment.

In the 2000-2001 economic crisis, a significant institutional change emerged in the exchange rate system, intended to reduce the over-valuation of the lira and bring it to its real rate. Between 1960 and 1980, the exchange rate system was fixed. From 1985 to 2001 , it was a managed exchange rate system. ${ }^{26}$ In the early 2000 s, Turkey finally adopted the floating exchange rate system, which eliminated speculation on the lira, although the currency acquired an over-valued exchange rate because of short-term capital flows. The exchange rate had been controlled by the government and the central bank until 2001. In 2001, due to the floating exchange rate system, the government lost its command of the exchange rate, which gave independence to the CBRT. The last major depreciation of the lira in 2001 occurred due to an institutional change to the floating exchange rate (see Fig. 3). Nevertheless, wage rate growth and inflation were still high, and the lira remained over-valued. This shows that Turkey was unable to implement sufficient institutional changes to leave the over-valued currency model. ${ }^{27}$ In other words, Turkey could not diminish path dependency and develop an institutional complementarity.

The CBRT became independent from the government and able to control interest rates to manage the exchange rate system. In addition, the central bank adopted a price stability policy and, for the first time, an inflation targeting system was adopted to decrease the devastating inflation in the Turkish economy. These institutional changes necessarily brought a control on wage rate growth, which declined dramatically after the 2000-2001 economic crisis. Thus, the ULC growth of export goods decreased to $7.5 \%$ and inflation fell to $10.6 \%$, one of the lowest levels in the Turkish economy in the 2000s, although it did not reach the level of developed countries or of the period before 1960 (Ünal 2016a).

A large number of privatizations were enacted. ${ }^{28}$ Increasing privatization severed the link between public industries and the trade unions, which had carried out collective bargaining agreements with the government. To minimize the industrial and commercial activity of public industries, the Privatization Board of Turkey aimed to develop a liberal market based on competition, in order to reduce the financial burden on the budget and contribute to the economy in terms of infrastructure and investments. The high levels of privatization also engendered deregulation in the wage-labor relation, which increased the flexibility of labor. Privatization increased and workers were laid off from public industries. Relatively low wage growth compared with the pre-2003 period became part of the economy. Competitiveness of the Turkish economy in international

\footnotetext{
${ }^{25}$ It must be noted that the sectoral share of workers in the service sector also increased significantly. It was $43.4 \%$ in 2003, and 51\% in 2014. That means that after Turkey reaches the technological frontier, it might make the sectoral share of service workers increase consistently greater than that of manufacturing. Similarly, this process was experienced by developed countries in the 1970 s.

26 The anticipated movements of exchange rates have an influence on inflation. The high volatility of the exchange rate has been associated with increasing interest rates and low investment. The floating exchange rate system eliminated speculative attacks on the exchange rate system and decreased its volatility, which contributed to the economic and political stability of Turkey.

27 For additional information, see Ünal (2016a, 2017), who discussed the large part of institutional changes in the exchange rate system and income policies in the 2000s.

28 For additional information see privatization implementations of Privatization Administration http://www.oib.gov.tr/ program/uygulamalar/1985-2004_years_table.htm accessed on November 10th, 2016.
} 
trade saw a relative improvement. Thus, the regulations progressed in tandem with export growth, becoming more consistent in the 2000s.

The government's intervention into the economy was decreased by deregulation policies. However, its intervention into income policies continued for public workers, minimum wage earners, and collective bargaining. The role of government changed and gained more prominence for attracting investments. The government supported export industries based on private companies and implemented promotion policies for foreign direct investment inflows on a large scale. Therefore, the mode of economy took the form of an excessively open economy, which was stimulated by the Customs Union and EU integration process. Nevertheless, from a perspective of institutional complementarity, Turkey could not match the growth model of the countries discussed in Table 1, the conditions of 1980s. Because of contradictions between its macroeconomic and institutional factors prior to 2003, Turkey had high ULC growth in exports, which decreased its competitiveness and failed to increase its ability to become a stable country in terms of inflation, exchange rates and trade deficit. In the 2000s, the over-valued currency model remained the main impediment to competitiveness, and the trade deficit remains a problem today. ${ }^{29}$

The institutional changes from 1950 to 2003 showed that Turkey could not maintain the low inflation and stability that it had enjoyed until the end of 1950s. The institutional changes that were developed in the 1960s and 1970s became the main reasons behind high ULC growth and an over-valued currency, influencing income policies and making the Turkish economy relatively uncompetitive in the global economy. Although Turkey's economic configuration gained stability compared with the 1970s, macroeconomic factors in Turkey continued to prove relatively unstable in the 2000s and 2010s. As seen in Table 7, wage growth remained excessively high, approximately $15.0 \%$, whereas GDP growth was just $4.4 \%$. Unstable income policies caused high inflation-around $7.9 \%$ and depreciation in the lira of approximately $13.2 \%$.

Discussion in the paper of economic transformation in the Turkish economy can be summarized as follows. First, the country followed a path which leads from agricultural growth to manufacturing growth. To reach manufacturing growth, the country experienced mechanization and technological changes. Thus, workers moved into the manufacturing sector and became more sophisticated in order to engage in production, which was supported by domestic consumption. This technological change made macroeconomic factors more important. Second, international trade is an insertion to global economy in the development path that contributes to export growth via the manufacturing sector. At this stage, the country experienced large increases in the export goods of the manufacturing sector compared with that of the agricultural sector, and rising GDP. Third, the export growth has become the main dynamic of economic growth and the main strategy since the 1980s. In this path of transformation, deregulation policies have gained importance. Fourth, income policy gained a crucial role in export growth, but was not designed according to macroeconomic factors. Lower cost production has been adopted by the developed countries after the 1980s to decrease inflation and compete internationally. Over-valued currency model has become significant barriers to the

${ }^{29}$ For instance, 1980, trade deficit was approximately 5 billion US dollars, but in 2014, it was 80 billion US dollars. Source: TurkStat (foreign trade by years). 
Table 7 Macroeconomic factors of Turkey (annual rate, unit: \%, 2011-2015). Source: GDP growth, wage growth (compensation of employees, current LCU) and inflation (consumer price) were derived from the World Bank. Exchange rate is from OECD (MEI)

\begin{tabular}{llll}
\hline Wage growth & GDP growth & Inflation & $\begin{array}{l}\text { Change rate in the lira } \\
\text { against the US dollar }\end{array}$ \\
\hline 15.0 & 4.4 & 7.9 & -13.2
\end{tabular}

improvement of economic structures in Turkey. ${ }^{30}$ Finally, institutional changes are the main dynamics in the creation of stability in economic process. The government plays the key role in establishing important institutional factors. Without proper institutional changes, technological transformation cannot be supported, a stable economy cannot be provided and the country cannot catch up with developed countries. ${ }^{31}$

In consequence, the common problems discussed in this work resulted from the lack of proper institutional changes in the Turkish economy, which are necessary for its stable development since contemporary macroeconomic factors are not appropriate to bring a favorable position, and cause high inflation, high volatility in the exchange rate, a high trade deficit, slow growth in exports and low competitiveness, all of which are unintended and undesirable consequences for sustainable development. The most important problem became evident as high costs of production caused by high wage rate growth surpassed the productivity growth of export goods, and monetary policies, in connection with income policies, the over-valued currency. These two problems are important impediments to Turkey's achieving low ULC growth, reaching the position of developed countries and completing its economic transformation. Furthermore, poor macroeconomic factors, which were not supported by institutional changes because of path dependency coming from closed economic periods, and slow transformation, weakened the Turkish economy that caused unsuccessful economic performance and large trade deficit. The over-valued currency model must be transformed by new institutional changes in order to bring about lower wage growth, in line with the productivity growth of export goods. This process can be developed under new income policies by considering the productivity growth of export goods.

\section{Conclusion}

In this paper, stylized facts of structural transformation, macroeconomic and institutional factors in Turkey have been discussed by incorporating growth models via inputoutput analysis. Turkey experienced two significant technological changes. First, the country transformed from one of agricultural growth to one of manufacturing growth. Second, the country left domestic consumption growth and became an export growth country. To make the process clear, the periods of transformation regarding institutional factors were analyzed between 1950 and post-2003. In the 1950s, Turkey followed agricultural growth strategies, promoted by government intervention based on liberal economic policies. This economic transformation brought mechanization, which was stimulated by the import of goods. Hence, Turkey created significant economic growth

\footnotetext{
${ }^{30}$ For additional information, see Ünal (2016a).

31 For instance, China's fixed exchange rate system supported its transformation through export-led growth. This institutional form made China more competitive in international trade. Exchange rate policy has a positive effect on China's economic growth.
} 
in the agricultural industry. The agricultural growth strategies developed manufacturing, and this process was supported by domestic consumption growth strategies within a protected and closed economy, created following state planned organization which prepared 5-year development plans in the 1960s and 1970s.

Between 1962 and 1985, the Turkish economy was based on domestic consumption growth that naturally brought about legislation for trade unions' rights of demonstration, strikes, and for employer unions, the right of lock-outs. The trade unions' industrial actions combined with radical left wing movements against the government that made decisions in the early 1980s to follow open economic policies and abandon protectionism, but these decisions failed to bring rapid success. However, the country continued implementing institutional changes according to export growth. In the period 19852003, the transformation of the economy was slowed down because of political and economic problems. Hence, Turkey became a country under the over-valued currency model due to its repressed exchange rate and high-cost production, which is defined in this work as a long transformation period until the end of the 2000-2001 economic crisis.

In the 2000-2001 economic crisis, the government began its strict transition program via privatizations and important institutional changes aimed at decreasing inflation. Thus, the country was able to create relatively consistent export growth compared with that of previous periods. Nevertheless, compared with the macroeconomic factors of the developed countries, which could implement successive deregulation policies and minimized ULC growth, Turkey still could not create an institutional complementarity between its macroeconomic and institutional factors, and it remains under the over-valued currency model, which increases its economic vulnerability in terms of inflation and the exchange rate, and still affects its economic performance today (see Table 8). 


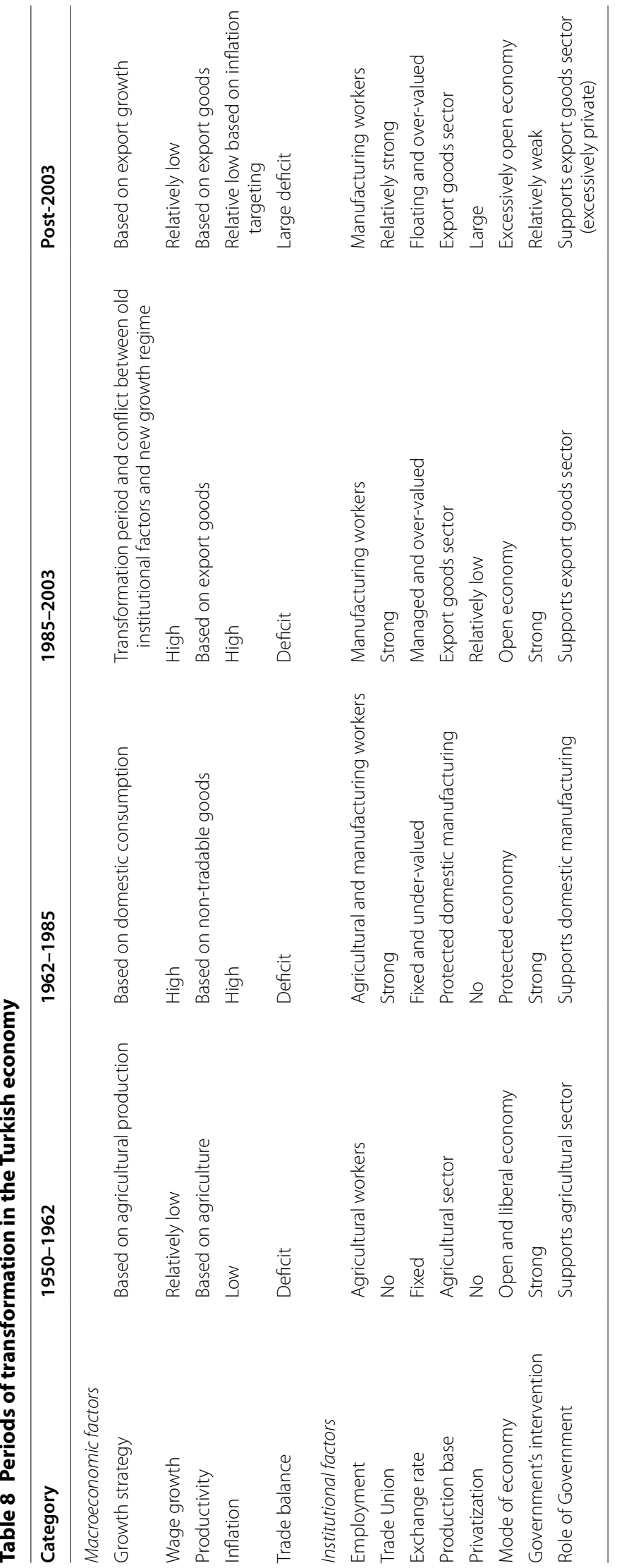


Acknowledgements

Thanks go out to Robert Charles Perry for his input and efforts on this paper.

Competing interests

The author declares that he has no competing interests.

Availability of data and materials

Various sources were used to collect data for the analyses. Each source of data and materials has been available and referred to throughout the paper wherever appropriate.

Consent for publication

Not applicable.

Ethics approval and consent to participate

Not applicable.

Funding

Not applicable

\section{Appendix}

\section{Calculating productivity growth of export goods and non-tradable goods}

$$
A x+y=x
$$

In this equation, $A$ is the technological coefficients' matrix, $y$ represents the vector of final demand and $x$ is a vector that shows the level of output.

$$
\begin{aligned}
& y=x-A x \\
& x=(I-A)^{-1} y
\end{aligned}
$$

The Leontief inverse matrix $(I-A)^{-1}$ is used to calculate the labor required to directly and indirectly produce one unit of each commodity. To measure the productivity growth of non-tradable goods and export goods, the equation below is used:

$$
\begin{aligned}
& y=(I-A) x \\
& \phi x=L
\end{aligned}
$$

In Eq. (7), $x$ is a column vector that shows the total amount of output for each commodity, $A$ is the input coefficient matrix, which shows the amount of domestic commodities used by the industry to obtain one unit of output. Furthermore, $\phi$ is a row vector that shows the amount of labor that is directly used to produce one unit of output in each industry. Finally, $L$ is a scalar that shows the total labor on the input-output table.

$$
\phi(I-A)^{-1}=v
$$

where $v$ is a row vector whose elements show the amount of labor that is directly and indirectly required to produce one physical unit of each commodity.

$$
v y=v(N+E)=L
$$

The amount of total domestic final demand is indicated by $N$, and the amount of total exports is indicated by $E$. Furthermore, the shares of each commodity in this total are indicated as column vectors $n$ and $e$, respectively.

$$
v_{\mathrm{n}}=\sum_{k=1} v_{k} n_{k} \quad \text { and } \quad v_{\mathrm{e}}=\sum_{k=1} v_{k} e_{k}
$$


In the equation, $v_{\mathrm{n}}$ and $v_{\mathrm{e}}$ are the vertically integrated labor input coefficients of nontradable goods and export goods, respectively. Labor productivity is calculated by means of vertically integrated input labor coefficients in each factor in both demand and exports. ${ }^{32}$ These coefficients are multiplied with price deflators. ${ }^{33}$ If the coefficients decrease, the productivity of non-tradable goods and export goods increases.

Figures 6, 7, 8 and Tables 9, 10, 11, 12 mentioned through the paper are inserted as follow:

32 For additional information, see Ünal (2016a).

33 Deflators were derived and calculated from the UN database using "national accounts estimates of main aggregates" and "GDP by type of expenditure" categories. Deflators of Turkey were calculated from data derived from TurkStat (GDP in chain linked volume, $2009=100)$, national currency was converted into US dollars. $v_{\mathrm{e}}$ deflator is calculated from exports at current prices (US dollars) divided by exports at constant prices (US dollars). $v_{\mathrm{n}}$ deflator is calculated from domestic demand at current prices (US dollars) divided by domestic demand at constant prices (US dollars). The following equation was used: Domestic demand $=G D P-$ export + import. 

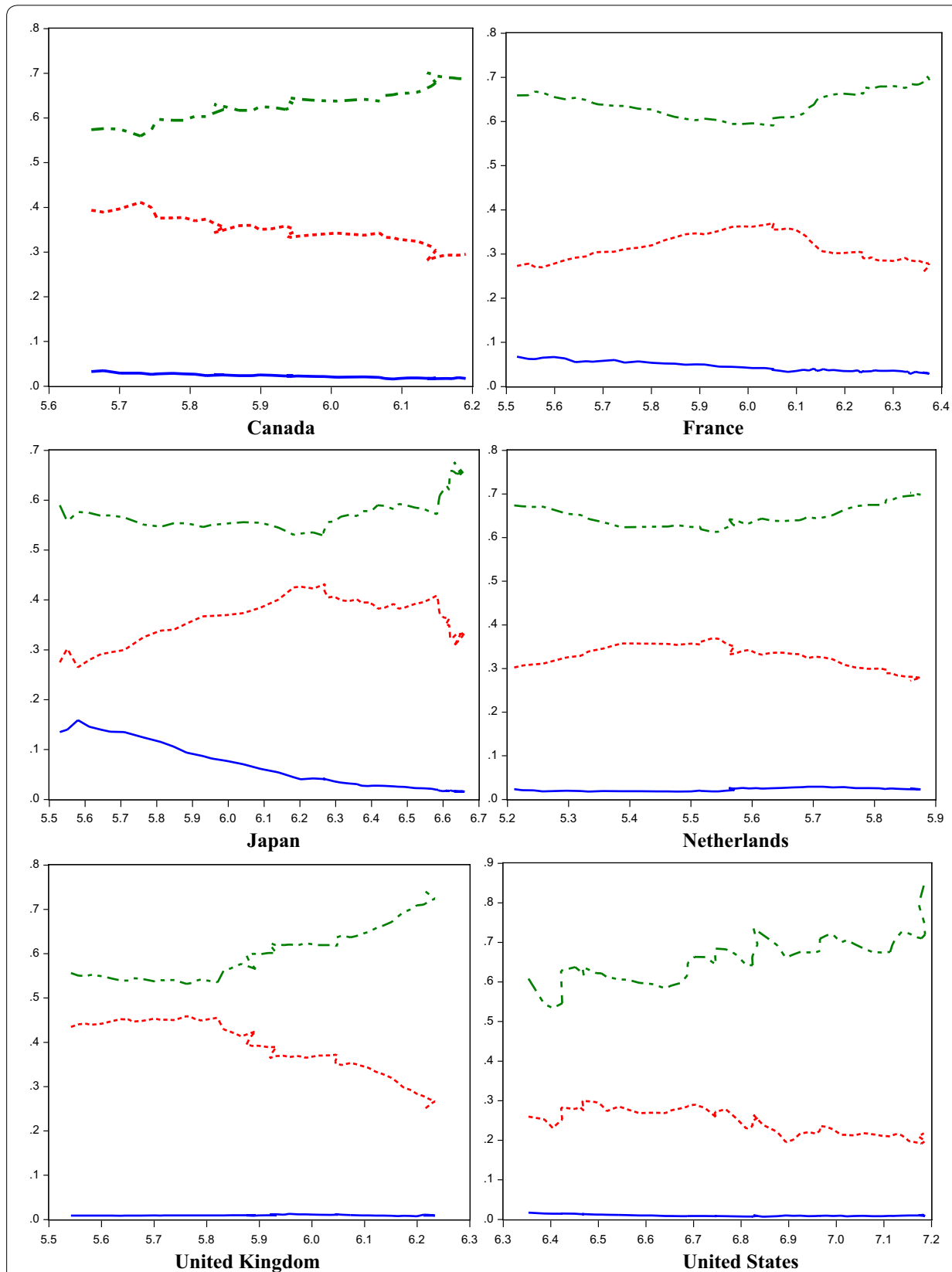

\section{- Agriculture
- - Manufacturing
- Service}

Fig. 6 Sectoral shares of value-added in the three sectors, and GDP in developed countries. Note: Horizontal line is Log (real GDP). Source: Author's calculations. Various sources were used to collect data. For Canada, UN data (national currency) was used between 1970 and 2014. For other countries, value-added at national prices $(2005=100)$ were derived from Groningen Growth and Development Centre: For France the period 1950-2009; for Japan the period 1953-2011; for Netherlands the period 1960-2009; for the United Kingdom the period 1949-2009; for the United States 1950-2010. For additional information see Fig. 1. 


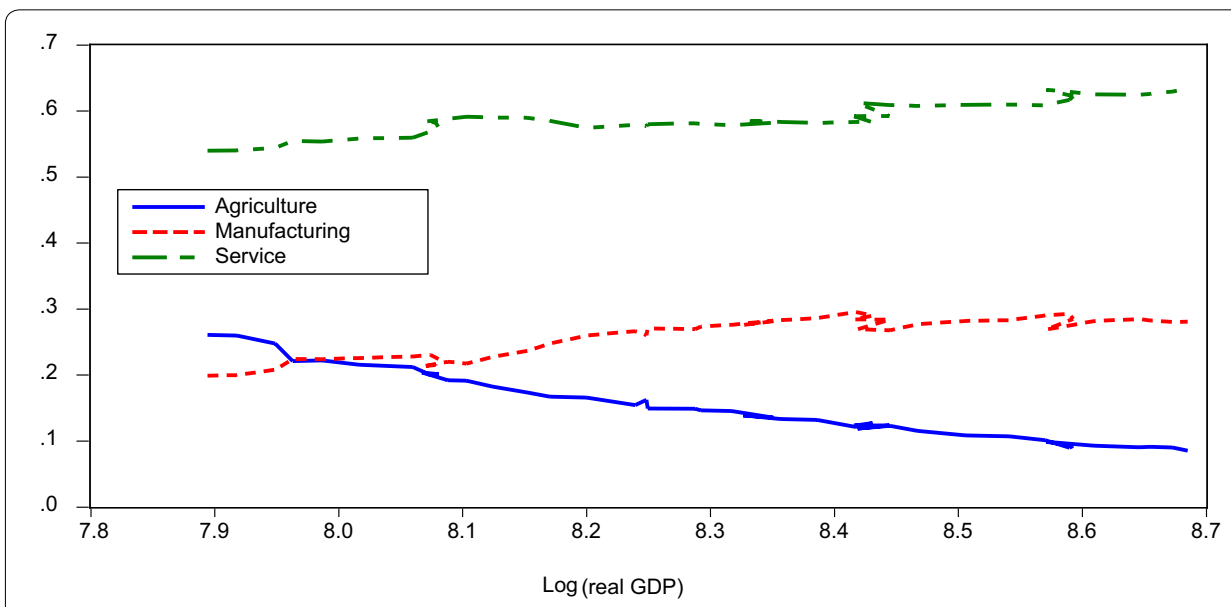

Fig. 7 Sectoral shares of value-added in the three sectors, and GDP in Turkey (annually, 1970-2015). Source: Author's calculation. Value-added $(2005=100)$ was derived from UN data (US dollars). For additional information see Fig. 2

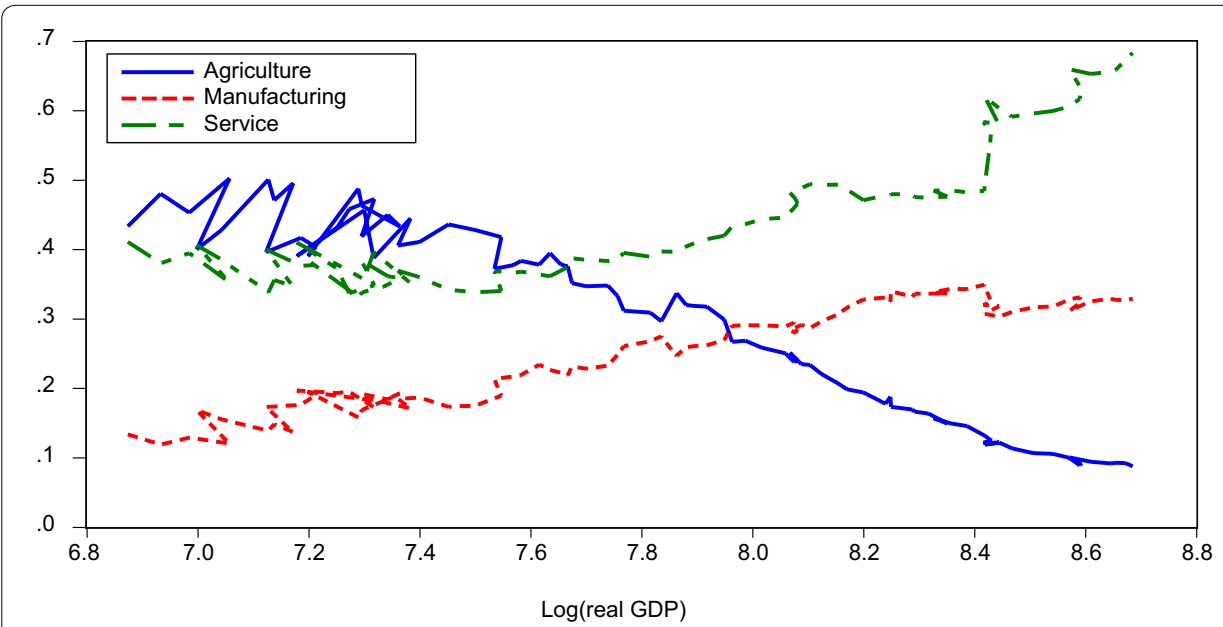

Fig. 8 Sectoral shares of production in the three sectors, and GDP in Turkey (annually, 1923-2014). Source: Author's calculation. Production is real value in each sector, derived from the Ministry of Development's report (Economic and Social Indicators between 1950 and 2014). For additional information see Fig. 2 
Table 9 Approximate sectoral wage growth in the countries (annual rate, unit: \%). Source: Author's calculations. For additional information see Table 1

\begin{tabular}{llcc}
\hline Country & Period & Non-tradable goods & Export goods \\
\hline Canada & $1971-1981$ & 9.9 & 11.2 \\
& $1981-1990$ & 5.2 & 5.3 \\
France & $1972-1980$ & 14.6 & 13.4 \\
& $1980-1990$ & 7.9 & 8.3 \\
Japan & $1970-1980$ & 11.7 & 11.8 \\
& $1980-1990$ & 7.5 & 7.0 \\
Netherlands & $1972-1981$ & 9.9 & 10.4 \\
& $1981-1986$ & 6.5 & 6.2 \\
Turkey & $1973-1985$ & 37.4 & 38.7 \\
& $1985-2003$ & 59.8 & 63.0 \\
& $2003-2011$ & 10.5 & 11.2 \\
United Kingdom & $1968-1979$ & 10.8 & 11.5 \\
& $1979-1990$ & 8.7 & 9.0 \\
United States & $1972-1977$ & 7.2 & 8.5 \\
& $1977-1990$ & & 8.5 \\
\hline
\end{tabular}

Table 10 Sectoral shares of production in developed countries (annual rate, unit: \%). Source: Author's calculations. Data were derived from OECD input-output tables. The data 1995 were derived from WIOD for Japan and Netherlands

\begin{tabular}{lllll}
\hline Country & Period & Agriculture & Manufacturing & Service \\
\hline Canada & 1971 & 4.3 & 52.1 & 43.6 \\
& 1981 & 5.0 & 52.9 & 42.1 \\
France & 1990 & 3.4 & 46.7 & 49.8 \\
& 1972 & 7.7 & 57.5 & 34.8 \\
& 1980 & 5.2 & 50.1 & 43.7 \\
Japan & 1990 & 4.0 & 43.0 & 53.0 \\
& 1970 & 4.5 & 62.6 & 32.8 \\
& 1980 & 3.0 & 57.7 & 39.3 \\
Netherlands & 1990 & 2.1 & 52.8 & 45.1 \\
& 1995 & 1.7 & 45.6 & 52.6 \\
& 1972 & 5.9 & 53.0 & 41.1 \\
& 1981 & 4.8 & 52.4 & 42.7 \\
United Kingdom & 1986 & 4.9 & 49.7 & 45.3 \\
& 1995 & 2.2 & 38.5 & 59.3 \\
& 1968 & 3.4 & 59.5 & 37.1 \\
United States & 1979 & 3.0 & 56.6 & 40.3 \\
& 1990 & 2.0 & 44.7 & 53.3 \\
& 1972 & 4.2 & 47.9 & 47.8 \\
& 1977 & 3.8 & 49.1 & 47.0 \\
& 1990 & 2.6 & 40.4 & 57.0 \\
\hline
\end{tabular}

The periods when the structural transformation experienced were considered. The italic emphasis the period when the sectoral share of production in service sector surpassed that in manufacturing sector 
Table 11 Wage growth in sectors and inflation in Turkey (annual rate, unit: \%). Source: Author's calculation. Wage growth was calculated by deriving data from TurkStat and WIOD input-output tables (compensation of employees)

\begin{tabular}{lllll}
\hline Period & Agriculture & Manufacturing & Service & Inflation \\
\hline $1973-1985$ & 38.6 & 35.3 & 35.3 & 38.5 \\
$1985-2003$ & 63.9 & 65.9 & 68.1 & 63.5 \\
$2003-2009$ & 10.8 & 12.7 & 15.6 & 11.5 \\
\hline
\end{tabular}

Table 12 Ratio of export to import by sector in Turkey. Source: Author's calculation. Ratios were calculated by deriving data from TurkStat

\begin{tabular}{llll}
\hline Period & Agriculture & Manufacturing & Service \\
\hline 1973 & 17.20 & 0.24 & 0.13 \\
1985 & 5.90 & 0.57 & 0.13 \\
2003 & 0.87 & 0.69 & 0.10 \\
2011 & 0.60 & 0.58 & 0.07 \\
2016 & 0.82 & 0.73 & 0.08 \\
\hline
\end{tabular}

\section{Publisher's Note}

Springer Nature remains neutral with regard to jurisdictional claims in published maps and institutional affiliations.

Received: 6 March 2017 Accepted: 27 October 2017

Published online: 16 January 2018

\section{References}

Aboites J, Miotti L, Quenan C (2002) Regulationist approaches and accumulation in Latin America. In: Boyer R, Saillard Y (eds) Régulation theory: the state of the art (trans: Shread C). Routledge, London, pp 280-288

Balassa B (1964) The purchasing-power parity doctrine: a reappraisal. J Polit Econ 72(6):584-596

Boyer R (1990) The regulation school: a critical introduction (trans: Charney C). Columbia University Press, New York

Boyer R, Hollingsworth JR (1997) The variety of institutional arrangements and their complementarity in modern economies. In: Boyer R, Hollingsworth JR (eds) Contemporary capitalism: the embeddedness of institutions. Cambridge University Press, Cambridge, pp 49-54

Boyer R, Saillard Y (2002) A summary of regulation theory. In: Boyer R, Saillard Y (eds) Regulation theory: the state of the art (trans: Shread C). Routledge, London, pp 36-44

Boyer R, Yamada T (2000) Introduction: a puzzle for economic theories. In: Boyer R, Yamada T (eds) Japanese capitalism in crisis: a regulationist interpretation. Routledge, London, pp 1-16

Briones R, Felipe J (2013) Agriculture and structural transformation in developing Asia: review and outlook, No. 363, ADB Economics Working Paper Series, Asian Development Bank

Herrendorf B, Rogerson R, Valentinyi A (2013) Growth and structural transformation, NBER working paper 18996, National Bureau of Economic Research

Jessop B, Sum NL (2006a) Introduction. In: Jessop B, Sum NL (eds) Beyond the regulation approach: putting capitalist economies in their place. Edward Elgar Publishing, Cheltenham, pp 1-10

Jessop B, Sum NL (2006b) Fordism and post-fordism. In: Jessop B, Sum NL (eds) Beyond the regulation approach: putting capitalist economies in their place. Edward Elgar Publishing, Cheltenham, pp 35-90

Kaldor N (1961) Capital accumulation and economic growth. Reprinted from the theory of capital, MacMillan \& CO LTD pp 177-222

King JE (2009) Nicholas Kaldor. Palgrave Macmillan, Hampsphere, p 77

Kuznets S (1957) Quantitative aspects of the economic growth of nations: II. Industrial distribution of national product and labor force. Econ Dev Cult Change 5(4):1-111

Kuznets S (1973) Modern economic growth: findings and reflections. Am Econ Rev 63(3):247-258

Michaels G, Rauch F, Redding SJ (2012) Urbanization and structural transformation. Q J Econ 127(2):535-586

Nakakubo H (2015) Industrial action and liability in Japan: a legal overview. Jpn Labor Rev 12(2):86-105

Samuelson P (1964) Theoretical notes on trade problems. Rev Econ Stat 46(2):145-154 
Solow RM (1970) Growth theory: an exposition. Clarendon Press, Oxford, pp 1-16

Thelen K (2014) Varieties of liberalization and the new politics of social solidarity. Cambridge University Press, New York, pp 154-192

Ünal E (2016a) A comparative analysis of export growth in Turkey and China through macroeconomic and institutional factors. Evolut Inst Econ Rev 13(1):57-91. https://doi.org/10.1007/s40844-016-0036-3

Unal E (2016b) How can turkey be part of the EMU? Turkey's economic and monetary integration into the EMU and the analyses of macroeconomic and institutional factors by export-led growth. Kyoto Econ Rev 85(1-2):2-41

Ünal E (2017, forthcoming) Turkey's Current account deficit problem and integration into the economic and monetary union of the European Union. Kyoto Econ Rev 86(1-2)

Uni H (2007) Export-biased productivity increase and exchange rate regime in east Asia. Kyoto Econ Rev 76(1):117-138

Uni H (2012) Comparative analysis of conditions for monetary integration: Europe and Asia. In: Boyer R, Uemura H, Isogai A (eds) Diversity and transformations of Asian capitalism. Routledge, London, pp 287-305

Verdoorn PJ (2003) Factors that determine the growth of labor productivity. In: McCombie J, Pugno M, Soro B (eds)

Productivity growth and economic performance: essays on Verdoorn's Law (trans: Thirlwall AP). Palgrave Macmillan, New York, pp 28-36

\section{Submit your manuscript to a SpringerOpen ${ }^{\circ}$} journal and benefit from:

- Convenient online submission

Rigorous peer review

- Open access: articles freely available online

- High visibility within the field

Retaining the copyright to your article

Submit your next manuscript at $>$ springeropen.com 